\title{
Analyzing the Effects of Re-use on Interior Spaces in Ispirtohane Building, Istanbul
}

\author{
Huseyin Emre Engin \\ Department of Engineering and Architecture, Avrasya University \\ PO box 61080, Trabzon, Turkey \\ E-mail: emrengin@hotmail.com \\ Hamiyet Ozen \\ Department of Architecture, Karadeniz Technical University \\ PO box 61080, Trabzon, Turkey \\ E-mail: hamiyeto@hotmail.com
}

\begin{abstract}
This research is prepared from a PhD thesis titled 'A Proposal Method For Analyzing The Effects on Re-Use of Historical Buildings: A Case Study on Industrial Building in Istanbul' completed by the first author in the Institute of Science and Technology, Karadeniz Technical University.
\end{abstract}

\begin{abstract}
Re-use of buildings and their surroundings with different functions considering contemporary comfort conditions and in this way, their integration with the city and its new environments is now one of the current issues that attract the interest of designers. But, non-compliant function selection and then repair techniques, the materials used and the irreversible interventions such as new inserts, cause significant changes in the interior of the building, affect the quality of the building. These approaches, which completely ignore the identity of buildings, undermine their original characteristics and it also destroys the values of being a cultural assets.

Based on the assumption of this problem, the aim of this study is to determine the effects of re-use interventions to the interior space in the 'Ispirtohane Building', which is a significant example of 'Istanbul Industrial Buildings', which is registered as immovable cultural assets as industrial heritage. The findings obtained at the end of the study were discussed in terms of generally accepted conservation principles and recommendations were made for future applications.
\end{abstract}

Keywords: Protection, Renovation, Reuse, Istanbul Industrial Building, İspirtohane Building

DOI: $10.7176 / \mathrm{JSTR} / 5-4-26$

\section{İstanbul İspirtohane Binasının Yeniden Kullanımında İç Mekâna Etkilerin İncelenmesi}

Özet

Kültür varlığı olan yapıların ve çevrelerinin çağdaş konfor koşulları dikkate alınarak farklı işlevlerle yeniden kullanılması ve bu sayede kente ve yeni çevreleriyle bütünleştirilmeleri, günümüzde tasarımcıların ilgisini çeken güncel konular arasında yer almaktadır. Fakat yapıyla uyumlu olmayan işlev seçimi, bunun akabinde uygulanan onarım teknikleri, kullanılan malzeme ve yeni ekler gibi geri dönüşü olmayan müdahaleler yapı iç mekânında önemli değişimlere sebebiyet vermekte, yapının niteliğini etkilemektedir. Yapıların kimliğini tamamıyla göz ardı eden bu yaklaşımlar, özgün özelliklere zarar vermekte ve kültürel varlık olma değerlerini yok etmektedir.

$\mathrm{Bu}$ sorunun varsayımından yola çıkılan çalışmada önerilen yöntemle, endüstri mirası kapsamında tescil edilerek taşınmaz kültür varlıkları olarak değerlendirilen 'İstanbul Endüstri Yapılarının' önemli bir örneği olan 'İspirtohane Binasının' günümüzde farklı işlevle yeniden kullanımı nedeniyle maruz kaldığ müdahalelerin iç mekânına etkisinin tespit edilmesi amaçlanmıştır. Çalışmanın sonunda elde edilen bulgular genel kabul gören koruma ilke ve yöntemleri açısından değerlendirilerek tartışılmış ve gelecekteki uygulamalar için öneriler sunulmuştur.

Anahtar Kelimeler: Koruma, Yenileme, Yeniden Kullanma, İstanbul Endüstri Yapıları, İspirtohane 


\section{Giriş}

Yapıların sonsuza değin ilk yapıldıkları amaç ve koşullarda varlıklarını sürdürebilmeleri ve hiçbir değişime uğramadan saklanmaları olası değildir. Ait oldukları dönem ve bağlamın etkisiyle şekillenen yapılar, değişen yaşam biçimi ve insan ihtiyaçlarına bağlı olarak sosyal, ekonomik ve fiziksel koşullarda meydana gelen farklılıklar nedeniyle beklenen performansı karşılayamaz duruma gelerek özgün işlevlerini kaybetmektedirler. Bu gibi durumlarda düzenli bakım ve onarımdan yoksun kalarak yıpranmaya başlayan yapıların, farklı işlevlerle değerlendirilerek yeniden kullanılması, korumanın bir boyutu olarak karşımıza çıkmaktadır (Altınok, 1998).

Yeniden kullanım çalışmalarında tarihi yapıların değerlerinin ve karakteristik özelliklerinin olumsuz etkilenmemesi için, öncelikle yapıların mimari özelliklerine uygun işlevler seçilmesi, yapıların taşıyamayacağı, içinde ve dişında köklü müdahaleler gerektirecek işlevlerin seçiminden kaçınılması gerekmektedir. Dolayısıyla amaçlanan şeyin özgün yapının korunması olduğu unutulmamalı ve yeni işlev bu doğrultuda sadece bir araç olmalıdır (Ahunbay, 1997). Çünkü yapının eski değerinin yaşatılması; okunabilir, görünebilir, algılanabilir hale getirilerek tarihi belge değerinin korunarak ortaya çıkarılmasıyla mümkün olmaktadır (Fielden 2003).

Yapıların yeniden kullanılmaları yoluyla gerçekleştirilen koruma yaklaşımlarında, müdahalelerin sınırları yasalar ve ilke kararları ile belirlenmiş olmasına rağmen, özellikle ikinci grup yapılarda cepheye yansımayan bazı değişikliklere izin veriliyor olması bir takım sorunları da beraberinde getirmektedir (Madran, Özgönül 2005). Tasarımcının bilgi birikimi ve deneyiminin yeterli olmamasının yanı sıra yapının özgün durumuyla ilgili yeterli araştırma yapılmaması, mimari özelliklerinin dikkate alınmaması; bu bağlamda seçilen işlev, uygulanan onarım teknikleri, kullanılan malzeme ve yeni ekler gibi geri dönüşü olmayan uygulamalar yapı iç mekânında önemli değişimlere sebebiyet vermekte, yapının niteliğini etkilemektedir. Yapıların kimliğini tamamıyla göz ardı eden bu yaklaşımlar, özgün özelliklerine zarar vermekte ve kültürel varlık olma değerlerini de yok etmektedir.

$\mathrm{Bu}$ sorunun varsayımıyla yapılan çalışmada, farklı işlevlerle yeniden kullanılan yapıların yeniden kullanımları nedeniyle maruz kaldığı müdahalelerin iç mekânına etkisinin tespit edilmesi amacıyla geliştirilen yöntem, endüstri mirası kapsamında tescil edilerek taşınmaz kültür varlıkları olarak değerlendirilen 'İstanbul Endüstri Yapılarının' önemli bir örneği olan 'İspirtohane Binasını' üzerinde uygulanmış ve çalışma sonunda elde edilen bulgular genel kabul gören koruma ilke ve yöntemleri açısından değerlendirilerek tartışılmış ve gelecekteki uygulamalar için öneriler sunulmuştur.

\section{Koruma ve Yeniden Kullanım}

\subsection{Koruma Kavramı}

Alsaç (1995) koruma kavramını herhangi bir nesne ya da olguyu elden geldiği kadar bozulmadan, o andaki durumunda tutmaktır diye tanımlar ve yalnız nesnelerin değil, kültür varlığı kapsamına giren gelenek, görenek, töre, tören gibi halk bilimsel olguların devamlılığının sağlanmasının da koruma çalışmaları içinde düşünülebileceğini ifade eder (Alsaç, 1995). Dünya Mirası Anlaşması çerçevesinde ise koruma kavramı; "anıtlar, yapı grupları ve sitler ile tanımlanan, kültürel mirası anlamak; malzemesinin korunmasını sağlamak ve gerekli olduğu halde tanıtımı, restorasyonu ve gelişimi için kullanılan yöntemlerin tümü" olarak tanımlanmaktadır (Omay Polat ve Can, 2008).

\subsection{Korunması Gerekli Yapı Kavramı}

Önemli olaylara sahne olan veya arkeoloji, tarih, sanat bakımından bir önemi ve özelliği bulunan, korunması ve değerlendirilmesi gerekli her türlü taşınmaz mimari eserler ve aynı nitelikteki heykeller "anıt" diye adlandırılır. Genişletilmiş anıt kavramı 1970'lerde türetilen bir terimle, "kültürel miras" olarak adlandırılmış ve anıt, yapı grupları, sitler olmak üzere üç bileşenden oluşan bir bütünün öğesi olarak yeniden tanımlanmıştır (Ahunbay, 1997). Anıtsallıktan uzak olsalar da, tümüyle işlevsel amacı olan gündelik yaşama ait yapılar da uzun bir süre geçtikten sonra, toplumsal tarihe ait bir bileşen olarak değer kazanmakta ve korunması gerekli yapılar olarak koruma kapsamına alınmaktadır (Alsaç, 1995).

\subsection{Korunması Gerekli Yapıların Yeniden Kullanımları}

Zaman içerisinde değişen yaşam koşulları, bu koşulların doğurduğu yeni ihtiyaçlar ve buna bağlı değişen mekanlar ve çevreleri günümüze ulaşan yapıların işlevlerinin de değişmesine sebebiyet vermektedir. $\mathrm{Bu}$ nedenle günümüze ulaşan yapıların çok azı başlangıçta amaçlanan işlevini sürdürebilmektedir. Han, hamam, kervansaray, manastır gibi yapı türleri bulundukları çevrede bu işlevi sürdüremediklerinden kullanım dışı kalırken, konut, otel, vb gibi yapılar ise günümüz konfor koşullarını sağlayamadıkları için, $\mathbf{2 5 0} \mid \mathrm{P}$ a g e 
endüstri yapıları vb. gibi üretim yapılan tesisler ise standart altı kaldıklarından işlevsel olarak eskiyerek terk edilmektedir.

İşlevini yitirdiği için terk edilen eski yapı düzenli bakım ve onarımdan yoksun kalmakta ve bu durum yapının eskimesine ve tahrip olmasına sebebiyet vermektedir. Bu durumda önemli özellikleri nedeniyle simgesel anlam ve değer taşıyan bu yapıların, anlamsal ve işlevsel açıdan uygun işlevlerle yeniden kullanılmaları gerekmekte, bu şekilde çağdaş yaşam içerisine adapte edilmeleri sağlanmalıdır.

Tarihi yapının farklı bir işlevle yeniden kullanılmasında ki amaç; yapıyı yeniden hayata kavuşturmak, işlevsel içerik kazandırmak, toplumsal ilişkilerin daimi bir mekan düzeni içerisinde geliştiği düşüncesi ile yapıyı topluma yararlı kılmak, çevrenin ondan yararlanmasını sağlamak olmalıdır (Başa, 2002). Yeniden kullanımın kültür varllğının devamlılığı için bir araç olduğu unutulmamalı, asıl amacın yapıyı korumak olduğu düşüncesinden uzaklaşılmamalıdır. Bu nedenle de yeniden kullanım çalışmalarında tarihi yapıların özgün değerlerinin, karakteristik özelliklerinin olumsuz etkilenmemesi için, öncelikle yapıların mekan kurgusuna uygun işlevler seçilmesi, yapılara ağır gelebilecek, içinde ve dışında köklü müdahaleler gerektirecek işlevlerin seçiminden kaçınılması gerekmektedir (Ahunbay, 1996). Bu durumlarda en ideal çözüm, yapının ilk işlevine yakın veya ilk işlevin kurgusuna uygun bir işlevle yeniden kullanılmasıdır. En az değişiklik, çağdaş konforun sağlanması ve geliştirilmiş bakım programları yapıyı bir bütün olarak korumak ve günlük yaşama sunmak için yeterlidir (Ersen, 1992).

\subsection{Yeniden Kullanımda Müdahale İlkeleri}

Yeniden kullanım uygulamalarında uluslararası yaklaşım geriye dönüle bilirliktir. Bu da genellikle yeni eklerin, bağımsız bir kurgulamayla eski strüktüre zarar vermeden yapılması, eklenen yeni elemanların kaldırılabileceğini öngören bir proje hazırlanmasıdır. Bu davranış, ileride başka koşullarda, yapının yine bugün bulunduğu duruma döndürülmesi amacını içermektedir. Tarihi ve estetik değeri yüksek, kültür ve sanat tarihindeki statüsü belli bir yapının restorasyonu, yeni bir işlevle de olsa 'geriye dönebilir' ilkesine göre yapılmalıdır. Restorasyonda amaç özel bir estetik ve kültür mesajını, bir uygarlık birikimi olarak geleceğe bırakmak olmalıdır. Yeni bir işlev verilerek kurtarılan yapı, gelecekteki yeni incelemeler, değerlendirmeler için de hazır olmalıdır (Kuban, 2000).

Yeniden kullanımda müdahalelerin nitelik ve nicelikleri açısından günümüze kadar birçok ilkeler ortaya konmuştur. 1877 'de William Morris'in ortaya koyduğu aynı zamanda S.P.A.B. (Society for the Protection of Ancient Buildings) adlı derneğin bildirgesinde yer alan ve bugünkü çağdaş restorasyonun temelini oluşturduğu düşünülen ilkeler, 18. yüzyılın sonlarında İngiltere de doğan 'her müdahalenin kendi dönemini yansıtması gereği” tartışmalarını ortak bir sonuca bağlaması açısından önemlidir. Özgün yapıya müdahalelerde eski ile yeni farkının tamamıyla ortaya konacak şekilde yapılması ve bunun için eski ve yeni malzemelerin dürüstçe göz önüne serilmesinin vurgulandığ 1 ilkelerde orijinalini taklit eden malzeme ve mekan biçiminden kaçınılması, orijinalmiş gibi yapılmaması gerektiği özellikle vurgulanmaktadır (Dayev vd. 1988).

Yine 1980'li yıllarda restorasyon çalışmaları için önemli bir yapıt olarak kabul edilen ve Bernard M. Feilden'in tarafindan yayınlanan Conservation of Historic Buildings adlı kitapta ise koruma çalışmalarında ağırlıklı olarak yapının belge niteliğinin korunmasının altı çizilmiş, müdahalelerin mümkün olduğu sürece geriye dönülebilir şekilde yapılması, ileride yapılacak yeni bir müdahaleye engel olmaması ve yapının tarihi verilerine sonradan ulaşmaya engel olmaması gerektiği vurgulanmıştır (Feilden 2003).

\subsection{Yeniden Kullanımda Müdahale Yaklaşımları}

Yeniden kullanımda özgün yapıya müdahale yaklaşımlarını üç başlık altında toplayabiliriz;

- Taklit etme

- Yorumlama (Benzer Yaklaşım)

- Zitlik (Kontrastlık)

a. Taklit Etme: Özgün yapının mimari elemanlarının renk, doku, malzeme ve yapım teknolojisi gibi özelliklerini olduğu gibi kullanarak zamanın ruhunu doğru biçimde yansıtamaması ve yapının inşa edildiği dönemle ilgili yanılsama yaratması sebebiyle olumsuz bir tasarım tavrı olarak kabul edilmektedir. Hangi işlemin ne zaman yapıldığını gizlemesi, bugün yapılmasına rağmen geçmişte yapılmış gibi gösterilmesi ve özgün yapıyla ilgili yanılsamalar oluşturması nedeniyle geçmişe saygı duymak, onu korumak yerine, ona zarar verebilmektedir. Kendi içinde yaratıcilıktan yoksun bir prensibe sahip olan taklit yaklaşımı bu haliyle de ancak özgün yapının değerini düşürmektedir (Engin, 2009).

251 | P a g e

www.iiste.org 
b. Yorumlama (Benzer Yaklaşım): $\mathrm{Bu}$ yaklaşım ise geçmişin bugünün diline uyarlanması çalışmalarıdır. Mevcut mimari dokuyla, yeni dokunun, kütle hareketi, gabari, açıklık oranları, malzeme seçimi, renk vb gibi öğelerle referans verdiği; ancak onu birebir taklit etmediği bir tavırdır. $\mathrm{Bu}$ tasarım yaklaşımda fiziksel açıdan özgün yapıyla benzeşmeler olmasına rağmen günün teknolojileriyle uygulanması açısından zamanın ruhunu da yansıtmaktadır (Engin, 2009).

c. Zitlık (Kontrastlık): Özgün yapının mimari elemanlarıyla, renk, doku, malzeme ve yapım teknolojisi açısından tamamen farklılaşan yeni tasarımlar zıt tasarım yaklaşımlarıdır. Zıt tasarım yaklaşımları mevcut doku içinde öne çıkarak dikkat çekerler. Tarihi dokuyla karşıtlık ilişkisi üzerinden bütünleşmeyi sağlayan bu tavır yapıldığı dönemi en net şekilde tanımlamaktadır. Eski ile yeniyi bir arada sergileyerek iki farklı dönemin özelliklerini de net biçimde yansıtması açısından önem kazanan zıt tasarım yaklaşımı 'çağdaş koruma kuramı' açısından yaygın olarak tercih edilen bir yöntemdir (Engin, 2009). Geçmiş dönemlerde Carlo Scarpa, Ignazio Gardella, Pierre Chareau, Bernard Bijvoet, Hans Dollgast gibi mimarlar yapıların yeniden kullanımlarında öykünme yerine "eski" ile "yeni”"yi yan yana koymayı tercih ederek karşıtlığı ilke edinmişlerdir (Powel, 1999).

\section{Materyal ve Metot}

\section{1. Çalışma Alanı}

Günümüzde özgün işlevinden farklı 'Kültür Merkezi ve Müzik Okulu' olarak yeniden kullanılan İstanbul Bakırköy'de ki 'İspirtohane Binası' örnek çalışma alanı olarak belirlenmiştir. Öncelikle yapıyla ilgili literatür çalışması yapılmış, yapının tarihçesi, mimari özellikleri ve geçmişten günümüze kullanımı araştırılmış, rölöve, restitüsyon ve restorasyon projeleri incelenmiş, bina içerisinde tespitler ve fotoğraflamalar yapılarak analiz için gerekli dokümanlar tamamlanmıştır.

\subsubsection{Bakırköy İspirtohane Binası}

\section{a. Konumu ve Mimari Özellikleri}

İspirto Fabrikası olarak da bilinen İspirtohane Binası, İstanbul ili Bakırköy ilçesi Ataköy 7.-8. Mahalle, 5178 Pafta, 1185 Ada, 1 Parsel üzerinde, resmi kayıtlara göre 11947 m2'lik bir alanda konumlanmıştır (Şekil 1) (Akın, Kahya, Salman, 2002).
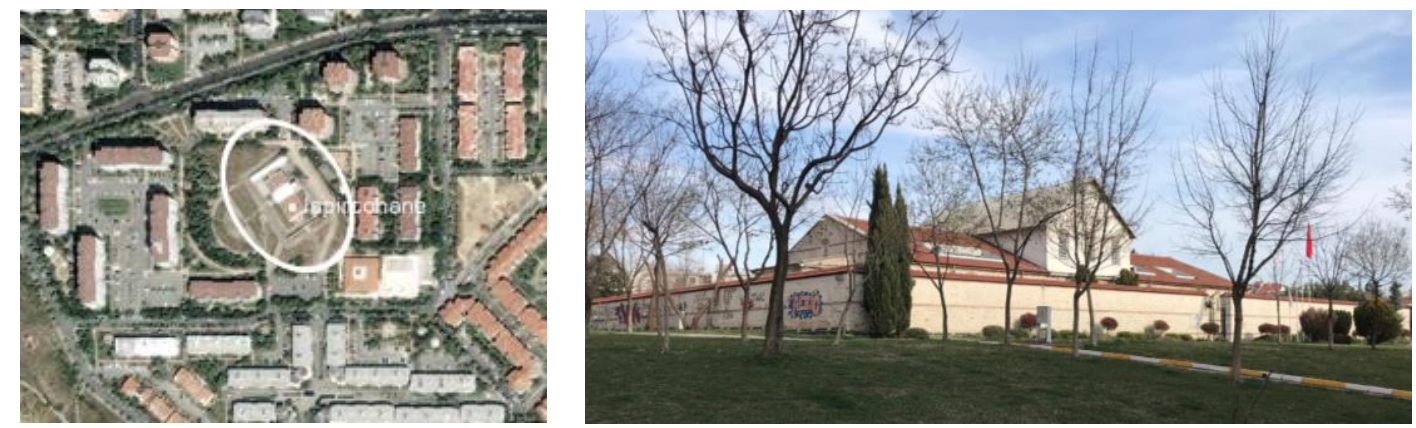

Şekil 1. İspirtohane'nin konumunu gösteren uydu görüntüsü (Bakırköy Musuki Vakfı, 2009) (solda) ve İspirtohane'den genel görünüm (sağda).

Dumansız barutu yıkamak için gerekli olan ispirtoyu/eteli elde edebilmek amacıyla 1917 yılında inşa edilmiş dönemin ilk ispirto fabrikasıdır. Yapıldığı dönemde İstanbul Baruthane yapı kompleksi içinde yer alan ve bu kompleksten günümüze ulaşan iki yapıdan biri olan İspirtohane Binasında ülkenin barut ihtiyacını karşılamak üzere savaş yıllarının yiyecek sıkıntısına rağmen nişastalı maddelerin (özellikle mısır) işlenmesiyle ispirto üretimi gerçekleştirilmiştir (İTÜ Mimarlık Fakültesi İspirtohane Ekibi, 2000).

Kullanımına ne zaman son verildiği kesin olarak bilinmeyen yapının İstanbul 2 Numaralı Kültür ve Tabiat Varlıklını Koruma Kurulu'nda bulunan dosyasındaki belgelerden vergi itibar yılının 1959 olduğu görülmektedir (İTÜ Geliştirme Vakfı Ar-Ge İşletmesi, 1998). 1958-59 yıllarında Türkiye Emlak Kredi Bankası'nın toplu konut yerleşmesini planladığı alanda kalması nedeniyle yerleştiği yaklaşık 4 milyon metrekarelik araziyle birlikte adı geçen kurumun mülkiyetine geçen yapı bu kurum tarafindan 24.10.1986 tarihinde 23 yıl süre ile restoran olarak kullanılmak üzere Hasır Gıda Sanayi'ne kiralanmıştır. Bu amaçla hazırlanan restorasyon projesiyle yapının özgünlüğünü büyük ölçüde ortadan kaldıran yeni müdahaleler, kurul onayı alınmadan hızla uygulamaya geçirilmiş, yapıda geri dönüşü zor, olumsuz değişiklikler yapılmıştır. Ancak yapılan bu izinsiz müdahaleler yüzünden yapının kullanıma açılması için ilgili

$252 \mid \mathrm{P}$ a g e

Www.iiste.org 
Koruma Kurulu'ndan gerekli izinler alınamadığı için restorasyon çalışmaları yarım kalmıştır. En son Bakırköy Belediye Başkanlığı tarafından 1997 yılında Emlak Bankası'ndan 49 yıllı̆̆ına kiralanan yapı için İTÜ Mimarlık Fakültesi'ndeki çeşitli disiplinlerden (restorasyon, mimari tasarım, yapı ve şehircilik) öğretim üyelerinin katılımıyla 1997-98 yıllarında rölöve, restitüsyon, restorasyon ve yeniden kullanımı projeleri hazırlanarak, Bakırköy İspirtohane Binası Kültür Merkezi ve Müzik Okulu olarak 9 Mayıs 2000’de kullanıma açılmıştır (Akın, Kahya, Salman, 2002).

$914 \mathrm{~m}^{2}$ alana sahip dar uzun bir dikdörtgen taban üzerine oturan tek bir kütleden oluşan yapı, dört yönde çevreleyen avlu duvarlarıyla yine dikdörtgen biçimli bir alanda konumlanmaktadır. Kısmi bodrum, giriş katı ve üst kattan oluşan yapının toplam kullanım alanı $1920 \mathrm{~m}^{2}$ 'dir. Yapının dış duvarları avlu duvarları gibi kaba yonu taş ve tuğla olarak örülmüş, almaşık bir düzen sergilemektedir. Yapı, batı cephesindeki ana giriş aksını vurgulayan iki katlı giriş holü ve onun kuzey ve güneyinde yer alan yan mekânlardan oluşmaktadır. Yan mekanlar özgün halinde tek eğimli ahşap çatıyla örtülüyken, ana mekan iç mekandan da algılanabilen çelik kolonların taşıdığı çelik kirişler üzerine oturan kuzey-güney yönünde iki eğimli ahşap makaslı çatı sistemli bir çatı ile örtülmüştür. Yapının giriş katı ve üst kat seviyelerinde düz atkılı / lentolu ve şevli pencere düzeni vardır. Cephelerin önemli öğelerinden biri üst katta ve yan giriş mekânlarında bütün yapıyı dolaşan özgün taş saçak silmesidir (İTÜ Geliştirme Vakfı Ar-Ge İşletmesi, 1998).

\section{b. Yeniden Kullanımı}

Binanın ana girişinin olduğu mekan, giriş holü ve çok amaçlı salona fuaye hizmeti verecek alan olarak düşünülmüş, kuramsal derslerin yapılabileceği değişik büyüklükte derslikler ve çalışma/prova salonları da bu katta yer almıştır (Şekil 2). Giriş holüne eklenen merdivenle ulaşılan birinci kat orta holü ise sürekli ve geçici sergileme alanı olarak planlanmış, prova/çalışma salonu ve çalışma atölyeleri ile öğretim üyelerine ait odalar bu katta yer almıştır. Bodrum katta ise çalışma ve prova salonları ile yönetim ofisi planlanmıştır (Akın, Kahya, Salman, 2002).
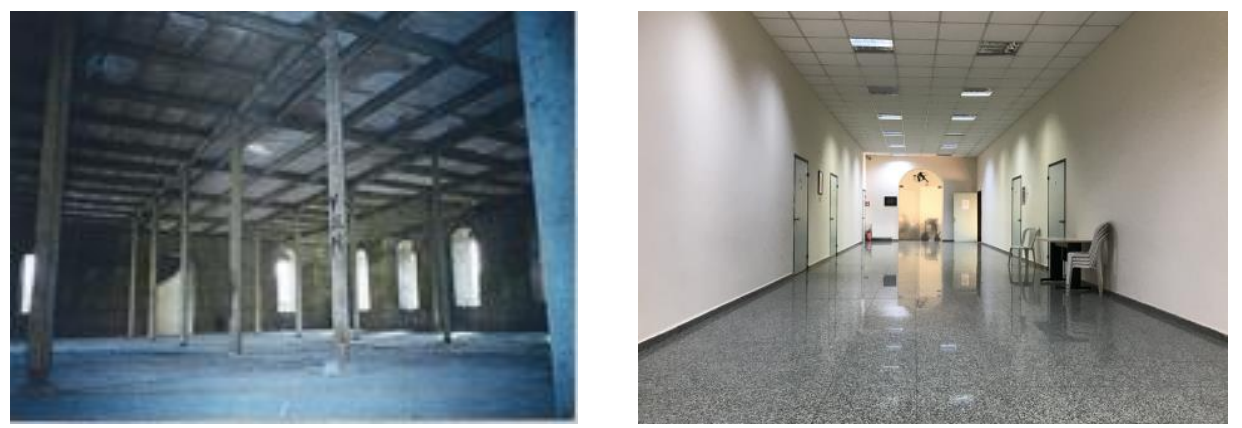

Şekil 2. İspirtohane'nin giriş katı güney bölümünün restorasyondan öncesinde (solda) (İstanbul 2 nolu KVKK arşivi, 1998) ve dersliklerin bulunduğu alan olarak kullanılan restorasyon sonrasından (sağda) görünümler.

\section{c. Yeniden Kullanımında Yapılan Müdahaleler}
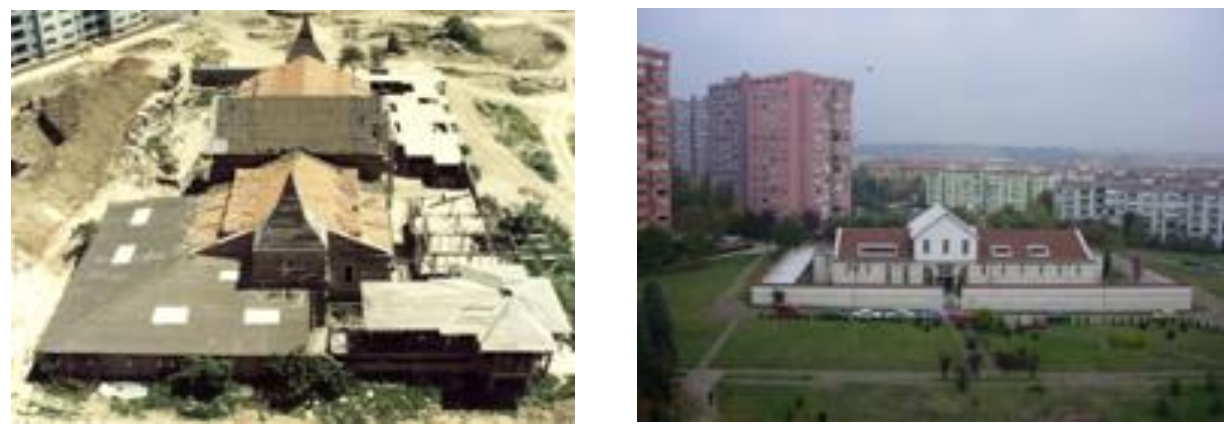

Şekil 3. İspirtohane'nin önceki restorasyonunda aldığı ekler (solda) (İstanbul 2 nolu KVKK arşivi, 1998) ve eklerin temizlendiği günümüzden görünümler (sağda). 
İspirtohane'ye ilișkin restorasyon kararlarında yapının geçirdiği tarihsel sürece yönelik verilerle oluşturulan restitüsyon çalışmaları ve yapının mevcut durumu esas alınmış, yapının kullanımı sürecinde zamanla aldığı eklerin belge olarak aynen korunması, 1990'larda yapılan ve yapının üzgün kimliğini büyük ölçüde zedeleyen niteliksiz müdahalelerin ise restorasyon ilkeleri doğrultusunda kaldırılması seklinde öngörülmüştür (Şekil 3) (Akın, Kahya, Salman, 2002).

Avlu duvarlarındaki açıklıklar kapatılmış, avluya inşa edilen betonarme platform ve platformlara ulaşan merdivenler ile müştemilat niteliğindeki ek binalar yıkılmıştır. Yine yan kanatların üzerine getirilen kat ve külah biçimindeki yeni üst örtüler, giriş cephesi üst katına yapılan betonarme çıkma ve çatıya önerilen yeni biçim ve yapının özgün görünümünü tümüyle değiştiren çatı pencereleri kaldırılarak, özgün olmayan ve tarihi yapının görünümünü etkileyen, sonradan eklenmiş niteliksiz ekler temizlenmiştir. Zemin kat ile birinci katı, özgün volta döşemenin bir kısmının boşaltılmasıyla birbirine bağlayan büyük betonarme merdiven ve son dönemde eklenen yan cephe döşemeleri gibi özgün olmayan ekler işlevsel ve strüktürel nedenlerle mevcut haliyle bırakılmıştır (Şekil 4) (İTÜ Geliştirme Vakfı Ar-Ge İşletmesi, 1998).
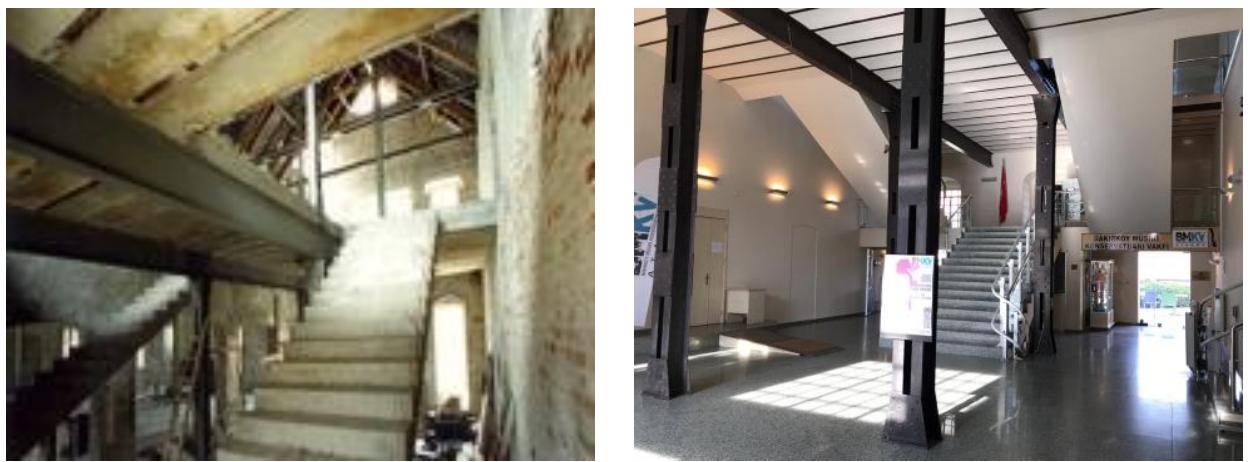

Şekil 4. İspirtohane'nin önceki restorasyonunda özgün volta döşemenin bir kısmı boşaltılarak eklenen betonarme merdiveninin restorayon öncesindeki (solda) (İstanbul 2 nolu KVKK arşivi, 1998) ve sonrasındaki görünümleri (sağda).

Bugün mevcut olmayan özgün elemanlar yapısal verilere dayanılarak yeniden değerlendirilmiş, son dönemde değiştirilen pencere boyutları özgün haline getirilmiş, üst örtüye eklenen çatı pencereleri kaldırılarak yeniden değerlendirilmiş, doğu cephesine çıkma eklenmiştir (Şekil 5). Özgün halinde var olduğu belirlenen bu çıkmanın tam olarak restitüsyonu yapılamadığından, çağdaş malzeme ile uygulanmış ve günümüz eki olduğu vurgulanmıştır. Giriş holü kuzey ve güney mekanı duvarlarındaki açıklıklar, özgün açıklık izleri algılanabilecek şekilde kapatılmıştır (Akın, Kahya, Salman, 2002).
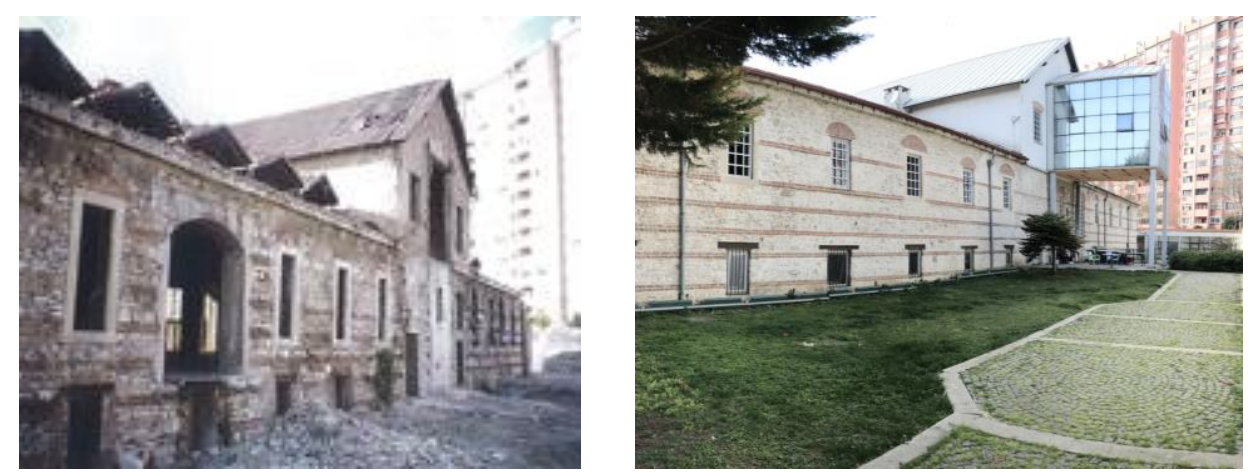

Şekil 5. İspirtohane'nin günümüze ulaşmadığı için çağdaş malzemelerle yeniden yapılan çıkmasının yer aldığ 1 doğu cephesinin restorasyon öncesi (İstanbul 2 nolu KVKK arşivi, 1998) (solda) ve sonrası (sağda) görünümleri.

Metal taşıyıcı elemanlar, volta döşemeler, ahşap çatı konstrüksiyonu, avlu ve binanın dış beden duvarlarındaki almaşık duvar örgüsü ve derzleri, pencereler üzerindeki tuğla kemerler gibi; özgün elemanlar sağlamlaştırılmış, temizlenmiş ve bozulmuş detaylar özgün haline uygun biçimde düzeltilmiştir. Yapı iç duvarlarında önceki işlev önerisinde uygulanmış çimento sıvalar sökülerek, 
yapının özgün haline uygun iç iklim kontrolü yapılabilecek alçı sıva uygulaması yapılmıștır. Ahşap çatı elemanlarının çürüklük mantarlı kısımları temizlenmiş, ilaçlama yapılmış ve eksik kısımlar bütünlenmiştir (Şekil 6). Kiremit altı tahtaları çürüklük mantarı nedeniyle tümden değiştirilmiştir (Akın, Kahya, Salman, 2002).
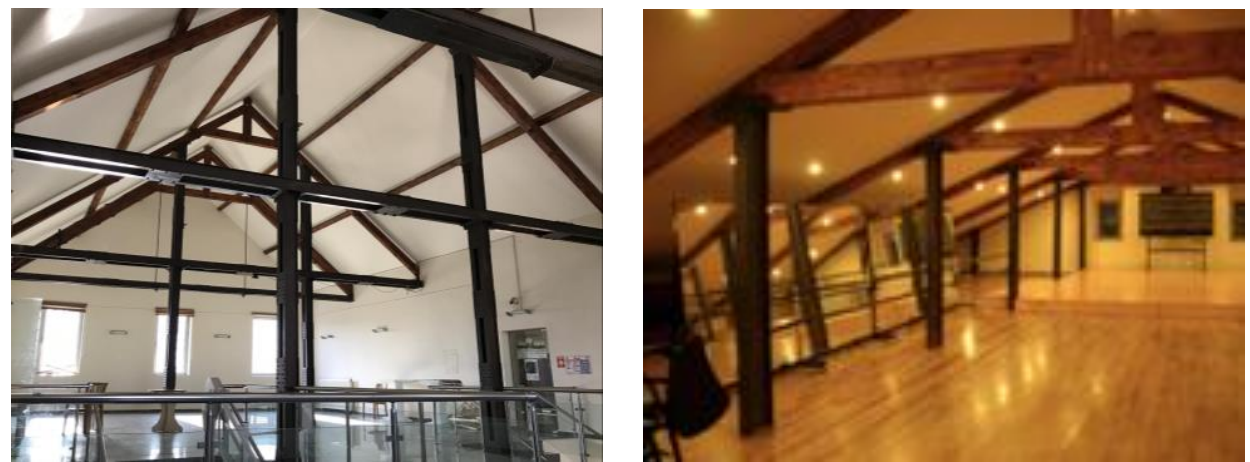

Şekil 6. İspirtohane'nin geçici sergi alanı (solda) ve prova odalarında ki (sağda) sağlamlaştırılarak korunan çatı makaslarından görünüm;

Yeni işleve yönelik olarak, kuzey avlu duvarına kafe/kantin olarak kullanılacak bir ek yapı ile iç mekân düzenlemelerinin gerektirdiği ayırıcı duvar, kapı, tavan vb. yeni mimari elemanların tasarlanması gibi yeni verilecek işleve uygun ekler ve elemanlar tasarlanmıştır (Şekil 7) (Akın, Kahya, Salman, 2002).
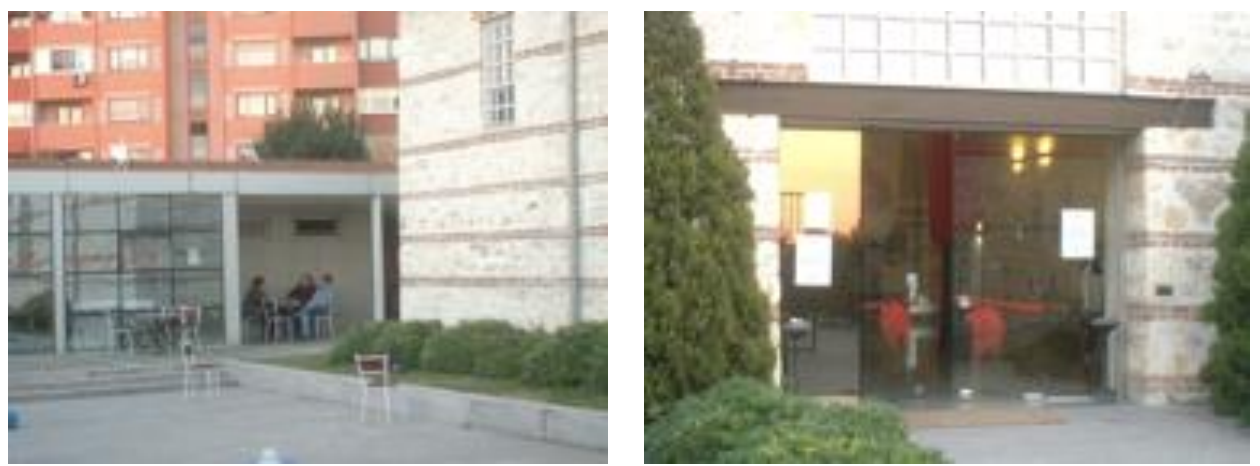

Şekil 7. İspirtohane'nin avlusunda çözümlenen kafe/kantin (solda) ve günümüze ulaşmadığı için cam kanatlarla yenilenen giriş kapısından (sağda) görünüm.

\subsection{Analiz Yöntemi}

Tarihi yapıların yeniden kullanımında iç mekâna etkilerin tespit edilmesine yönelik analiz tabloları, morfolojik yaklaşım yöntemlerinden morfolojik kart tekniğinden yararlanılarak geliştirilmiştir. İki boyutlu tabloların, bir boyutunda mimari elemanlar diğer boyutunda ise yeni işlevleri nedeniyle mimari elemanlara olası müdahaleler yer almış, böylece her bir yapı için tercih edilen uygulama yaklaşımları tespit edilerek birbirleriyle karşılaştırılmalarına olanak sağlanmıştır (Engin, 2009).

Yapılara yeni işlevi nedeniyle yapılan müdahalelerin; yapıların özgün mekânsal kurgusu ile özgün mimari strüktür ve elemanlarına etkilerinin analiz edilmesi amaçlanarak geliştirilen yöntemde iki aşama belirlenmiş, birinci aşamada literatür çalışması ile yapıların tarihsel gelişimi, mimari özellikleri, yeniden kullanım programı ve bu kapsamda yapılan müdahaleler hakkında bilgiler derlenmiş, ikinci aşamada ise ilk aşamada elde edilen veriler, yapıların yeniden kullanımlarında maruz kaldıkları olası müdahalelere bağlı olarak hazırlanan tablolarla analiz edilmeye çalışılmıştır. Bu anlamda üç farklı analiz tablosu hazırlanmıştır;

- Uygulanan müdahale yöntemlerinin analizi (Tablo 1)

- Mekansal kurguya müdahalelerin analizi (Tablo 2)

- Mimari strüktür ve elemanlara müdahalelerin analizi (Tablo 3) 
Çalışma kapsamında incelenen yapılara müdahalelerin eylem alanlarına göre olası farklı etkilerini de tespit edebilmek amacıyla 5 faklı eylem grubu belirlenmiş ve bulgular bu başlıklar altında değerlendirilmiştir. Buna göre,

- Sirkülâsyon Mekânları: Giriş ve mekânlar arasındaki bağlantıyı sağlayan ortak alanlar

- Ortak Kullanım Mekânları: İşlev programına bağlı olarak tüm kullanıcılara yönelik düzenlenen fuar, sergi, konferans salonu, kütüphane, çok amaçlı salonlar vb. gibi alanlar

- Özel mekânlar: İşlev programına bağlı olarak sadece belirli kullanıcılar için düzenlenen yönetim odaları, idari birimler vb. gibi kişiye özel alanlar

- Sosyal ve Rekreatif Mekânlar: Yapının işlevine katkıda bulunan sosyal aktiviteler için düzenlenmiş, dinlenme alanları, restoran, kafeterya vb. gibi alanlar

- Islak Mekanlar: Mutfak, Banyo, Lavabo vb gibi hizmet mekânları

olarak sınıflandırılmıştır (Engin 2009).

\subsection{Yapının Analizi}

Çalışmanın bu aşamasında İspirtohane yapısına restorasyon çalışmalarında uygulanan müdahale yöntemleri Tablo 1 ile tespit edilmiş, ardından Tablo 2 ile Mekânsal Kurguya Müdahale analizleri, Tablo 3 ile de Mimari Strüktür ve Elemanlara Müdahale analizleri yapılmıştır.

Tablo 1. İspirtohane Binası için müdahale yöntemlerinin analiz tablosu

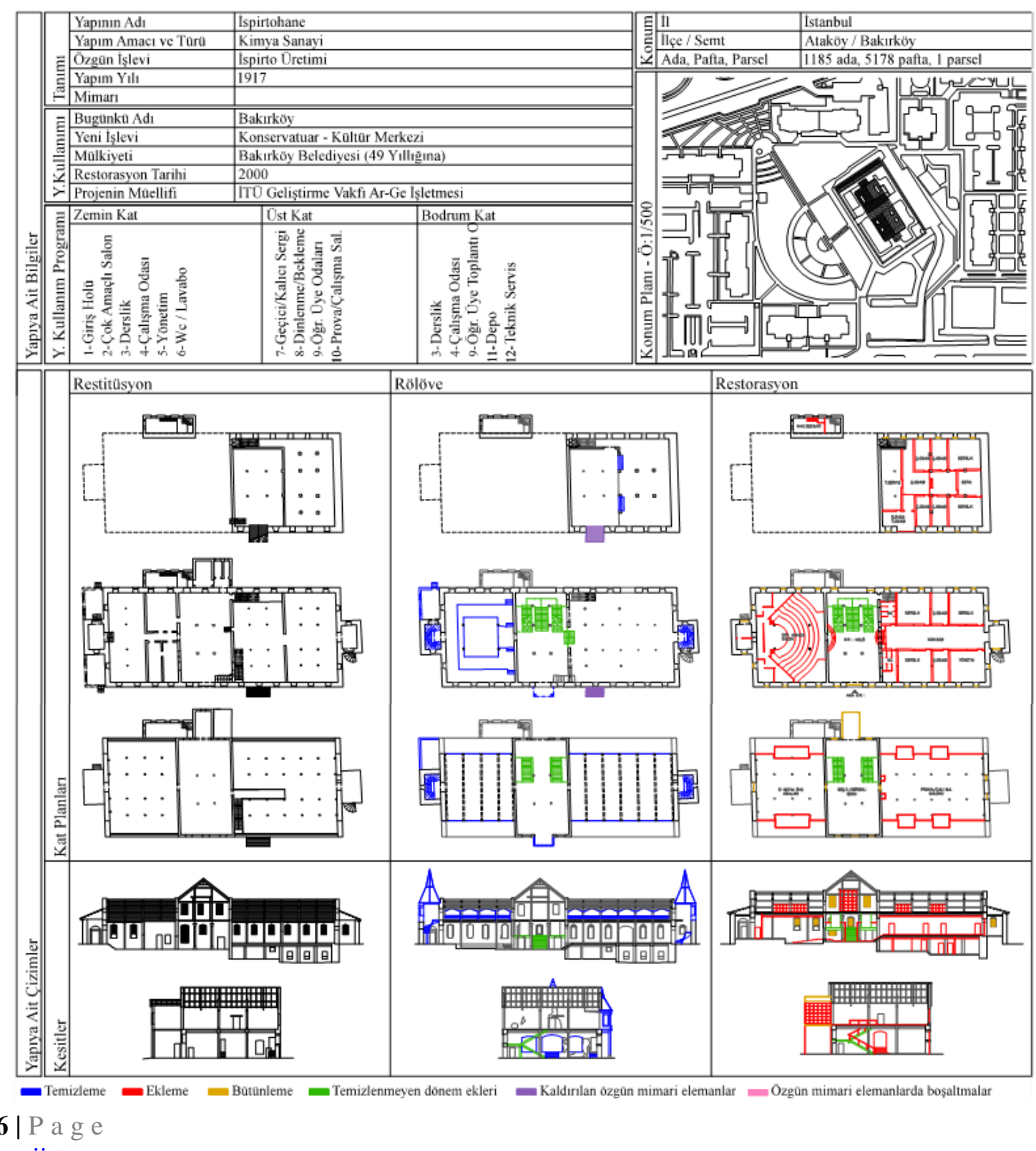

WwW.iiste.org 
International Journal of Scientific and Technological Research ISSN 2422-8702 (Online), DOI: 10.7176/JSTR/5-4-26

Tablo 2. İspirtohane Binası için mekânsal kurguya müdahale analiz tablosu

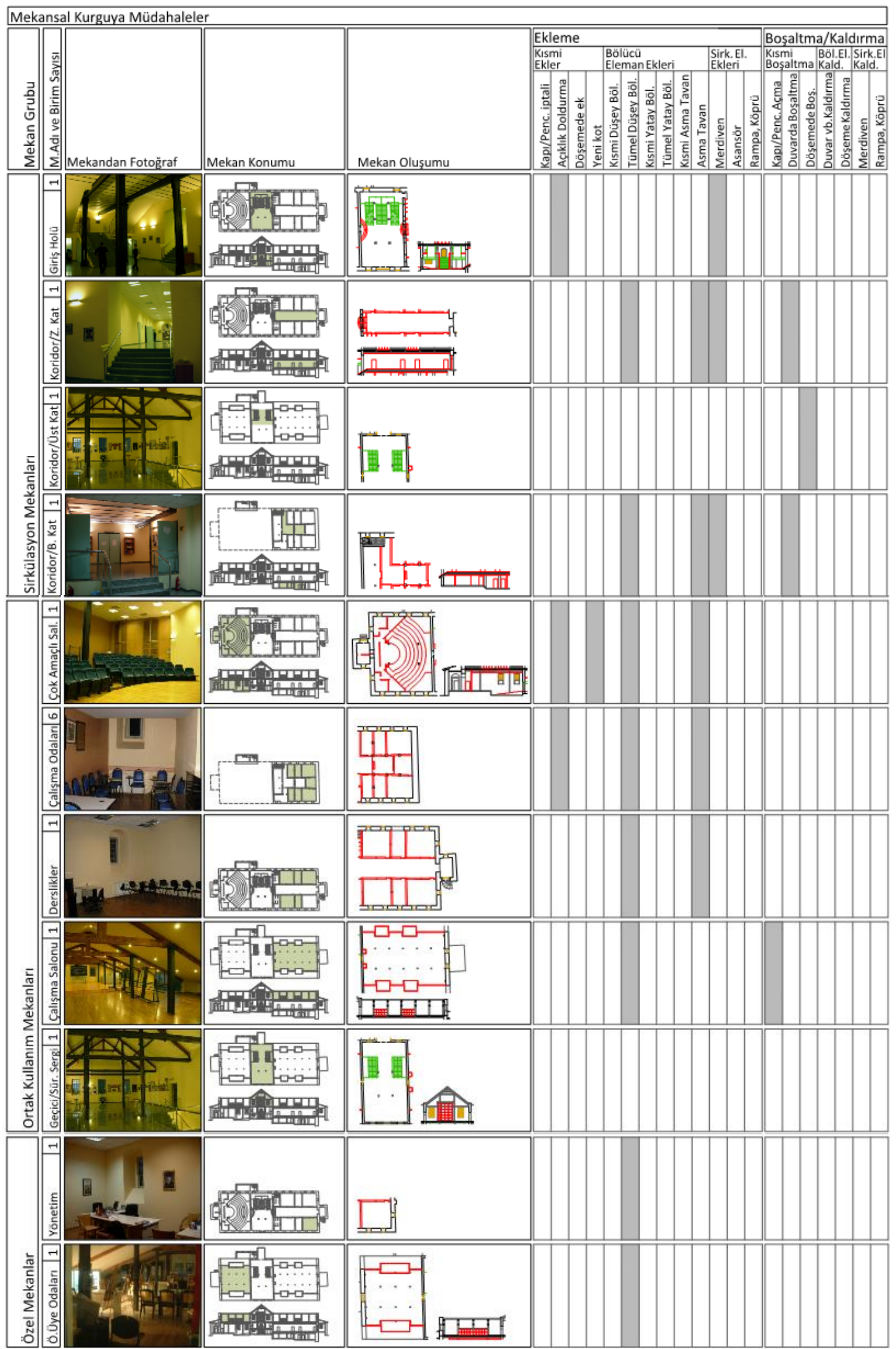




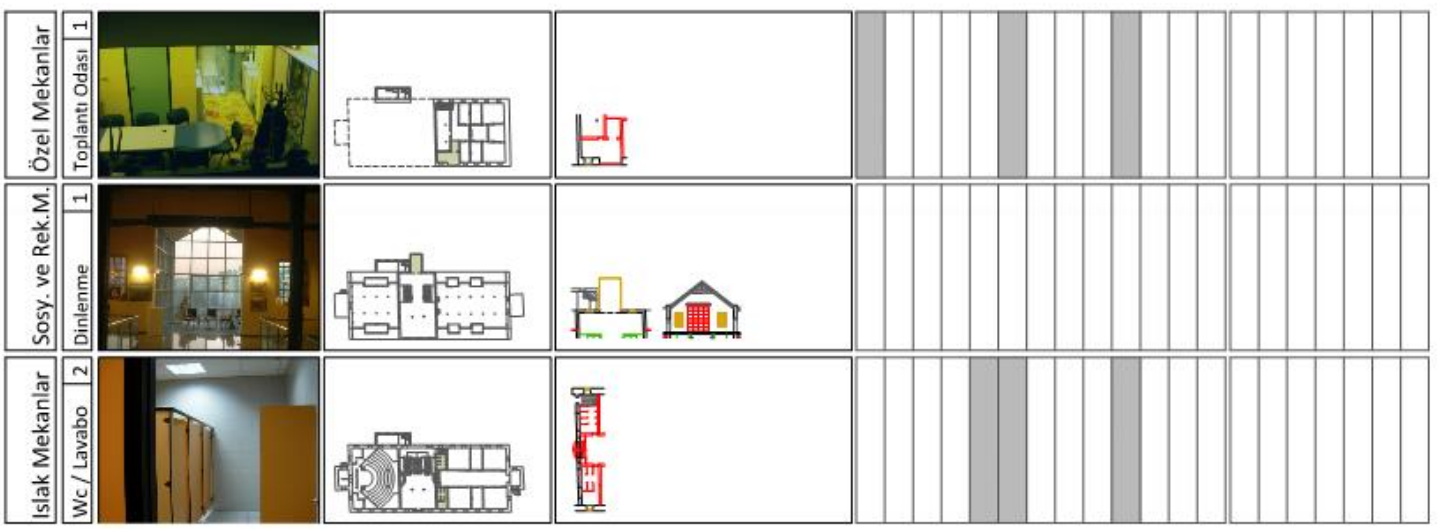

Tablo 3. İspirtohane Binası için mimari strüktür ve elemanlara müdahale analiz tablosu

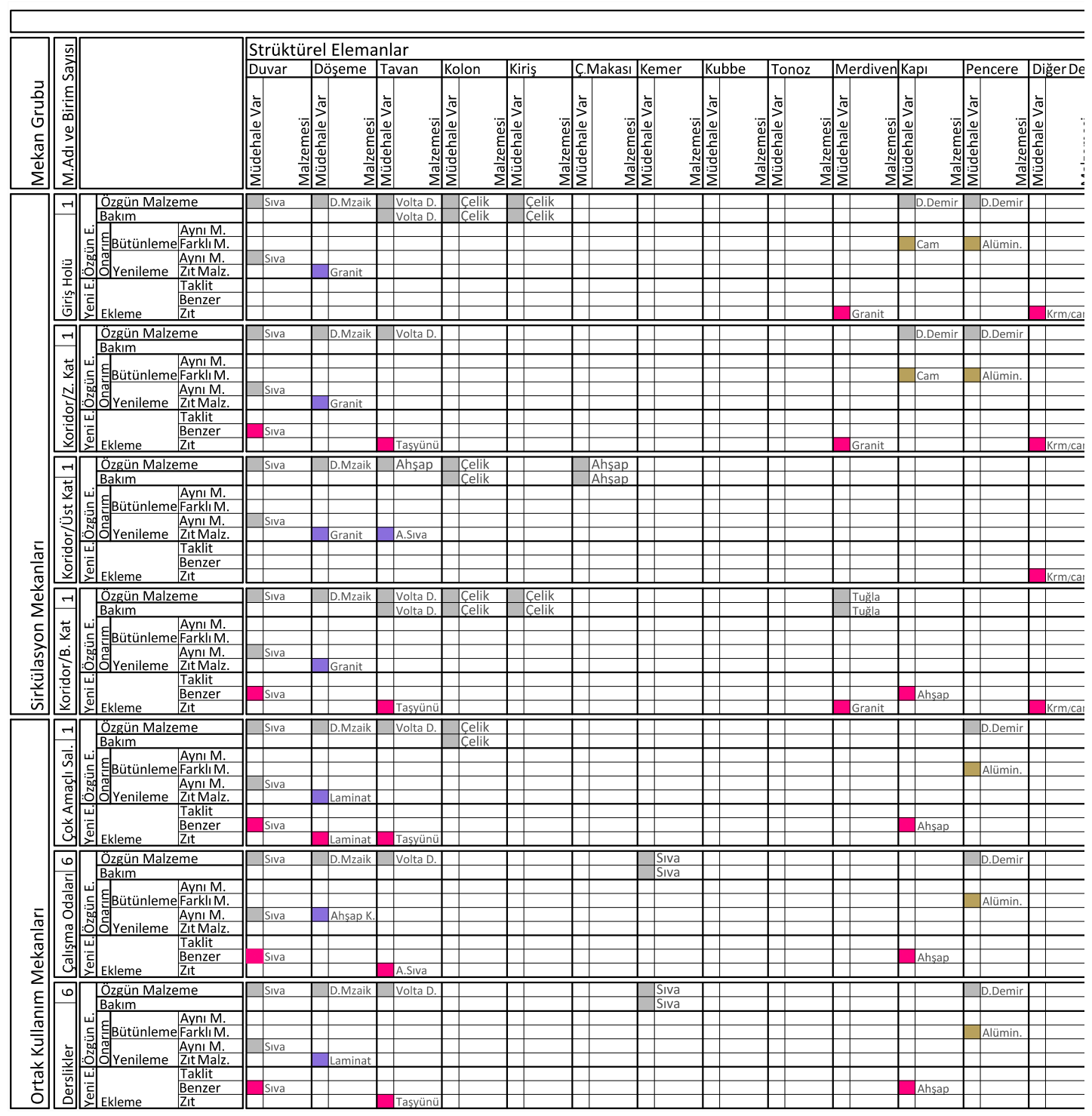




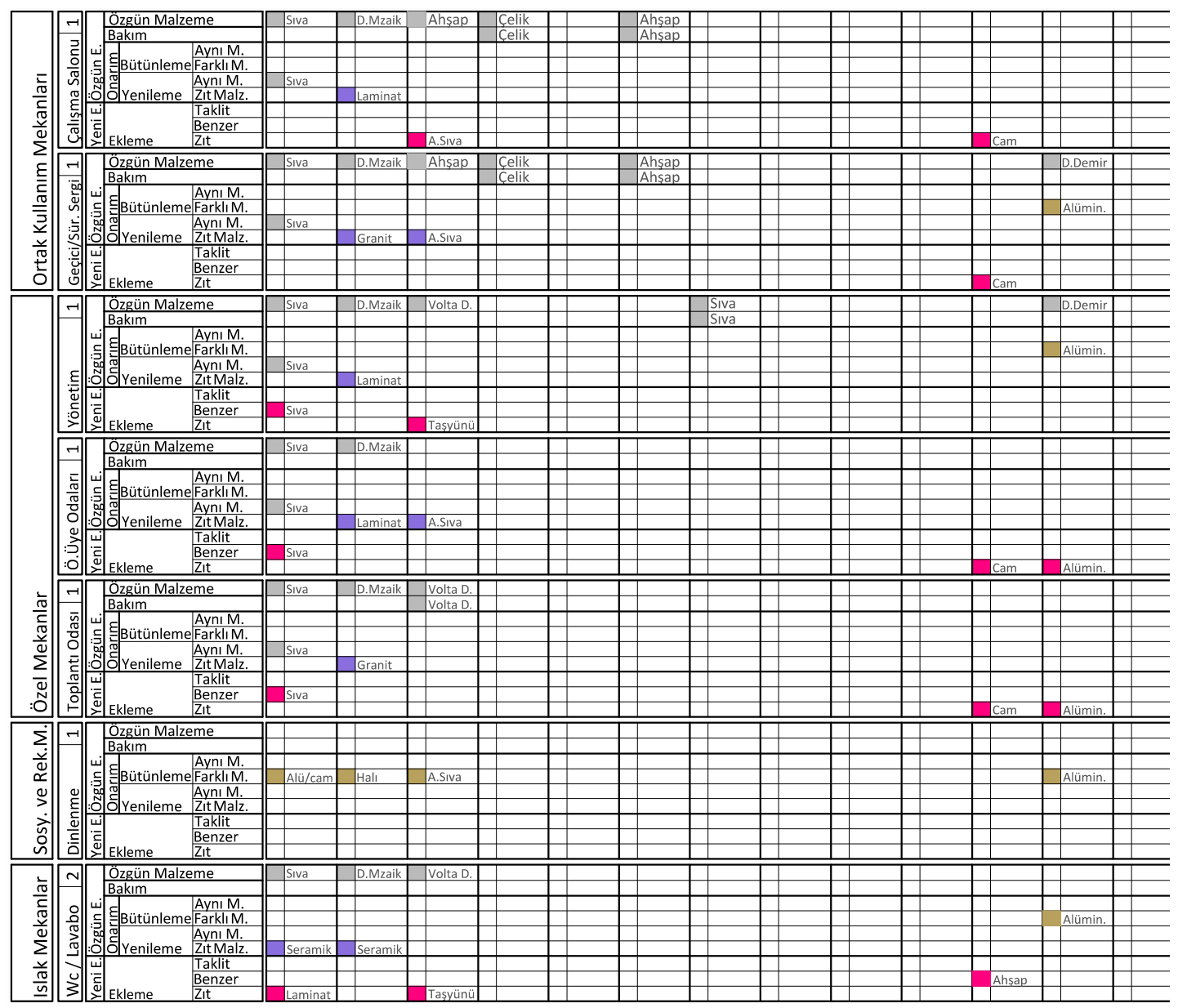

\section{Bulgular ve Tartışma}

\section{a. Uygulanan Müdahale Yöntemleri Açısından Değerlendirme}

Çalışma kapsamında incelediğimiz İspirtohane Binasının özgün işlevini kaybettikten sonra geçirdiği restorasyon çalışmalarında bir takım müdahalelere maruz kaldığı boş kaldığ 1 dönemlerde ise bir takım yapısal bozulmalara uğradığı anlaşılmaktadır. $\mathrm{Bu}$ nedenle yeniden kullanım çalışmalarında; sağlamlaştırma, temizleme, bütünleme, yenileme ve çağdaş ek gibi restorasyon tekniklerinin uygulandığını görmekteyiz.

Önerilen yeni işleve bağlı yapılan restorasyon çalışmalarında öncelikle yapısal bozulmaların giderilerek gerekli sağlamlaştırma işlemlerinin yapıldığı, önceki kullanımlarından kalan niteliksiz dönem eklerinin ayıklandığı, eksik elemanların tamamlandığı görülmüştür. Yapının önceki restorasyonunda avlusuna eklenen betonarme platform, müştemilat niteliğindeki ekler ve yan kanatların üzerine eklenen yeni katlar ve üst örtüsü temizlenirken, ana girişin olduğu hole eklenen merdivenler yeniden kullanımında işlevsel bulunması nedeniyle kaldırılmamıştır. Günümüze ulaşmayan doğu cephesindeki çıkma çağdaş malzemelerle tamamlanırken bodrum kat ve birinci katın kuzey ve güneyinde kaldırılan özgün duvarlar ise tamamlanmamıştır.

Yapının iç mekânında, yeni işlev kurgusu gereğince yeni mimari elemanlar eklenmiş, özgün mimari strüktür ve elemanlara bakım ve onarım çalışmaları yapılmıştır. Yapının avlusunda ise yeni işlevine hizmet eden kafeterya ve servis mekanları için çağdaş ek tasarlanmıştır.

\section{b. Mekânsal Kurguya Müdahaleler Açısından Değerlendirme}

Yapının yeniden kullanımına bağlı olarak özgün mekansal kurgusuna bir takım müdahaleler getirildiği görülmektedir. Bu etkileri müdahale türleri açısından değerlendirecek olursak;

\section{- Kısmi ekler ve boşaltmalar:}

Duvar ve döşemede açıklıkların doldurulması gibi kısmi eklerin, yeni pencere açılması ve döşemede boşluk oluşturulması gibi kısmi boşaltmaların yapıldığı görülmektedir. 
Ağırlıklı olarak ortak kullanım mekanları ve ıslak hacimlerde görülen kısmi ekler (Şekil 8), yeni işlev kurgusundaki mekanları oluşturabilmek için giriş holünün kuzey ve güney kısmını ayıran duvarlar arasındaki boşlukların kapatılması ve güney kısmından üst kata çıkan ancak günümüze ulaşmayan merdiven boşluğunun kapatılması şeklinde olmuştur.

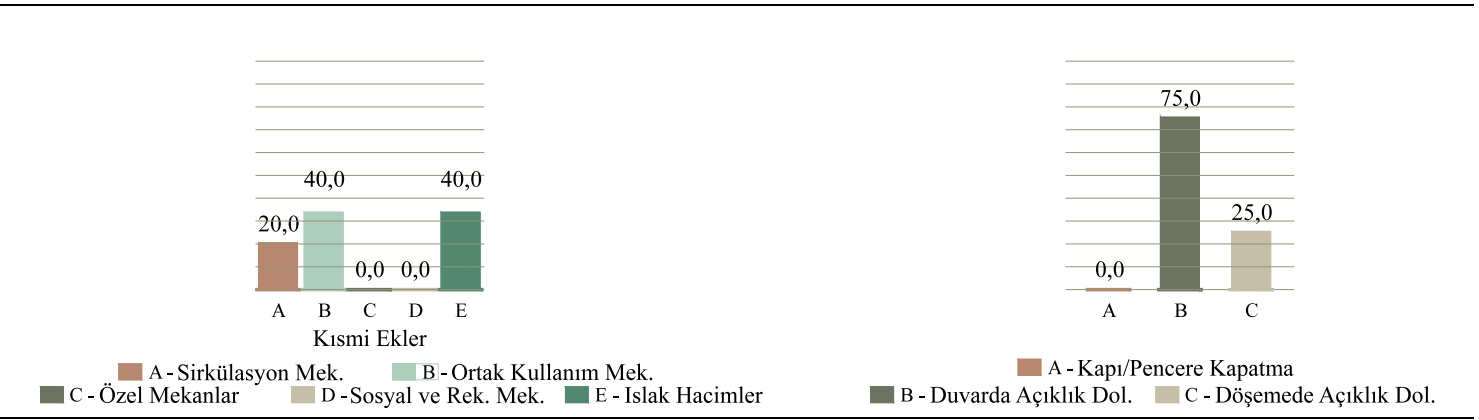

Şekil 8. Kısmi eklemelerin mekan gruplarına (sağda) ve türlerine (solda) göre dağılımı

Kısmi boşaltmalara ise ağırlıklı olarak sirkülasyon mekanlarında rastlanmaktadır (Şekil 9). Giriş holünden üst kata ulaşımı sağlamak için yerleştirilen yeni merdiven nedeniyle özgün volta döşemede yapılan boşaltma, giriş holünün güney duvarında derslikler için oluşturulan koridora ulaşmak için açılan boşluk ve bodrum katta özgün halinde bahçeden ulaşılan mekana geçiş yapmak için duvarda oluşturulan açıklık sirkülasyon mekanlarındaki kısmi boşaltmalar olarak karşımıza çıkmaktadır. Üst katın kuzey ve güney kısımdaki mekanların ışık alması için çatıda açılan yeni pencereler ise özel mekanlar ve ortak kullanım mekanlarına denk gelen kısmi boşaltmalardır.

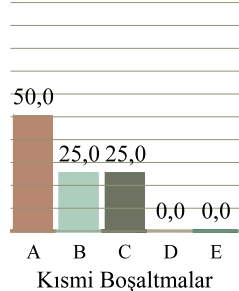

A - Sirkülasyon Mek

B-Ortak Kullanım Mek. C - Özel Mekanlar D - Dosyal ve Rek. Mek. E - Islak Hacimler

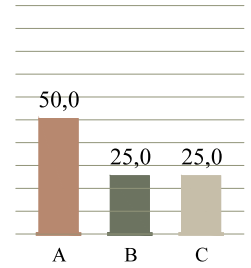

A - Kapi/Pencere Açma B - Duvarda Boşaltma C - Döşemede Boşaltma

Şekil 9. Kısmi boşaltmaların mekan gruplarına (sağda) ve türlerine (solda) göre dağılımı

\section{- Bölücü eleman ekleri ve kaldırılan bölücü elemanlar}

Yeni işlev kurgusu nedeniyle bir takım bölücü elamanlar eklendiği, bazı özgün bölücü elemanların ise kaldırıldığı görülmektedir.

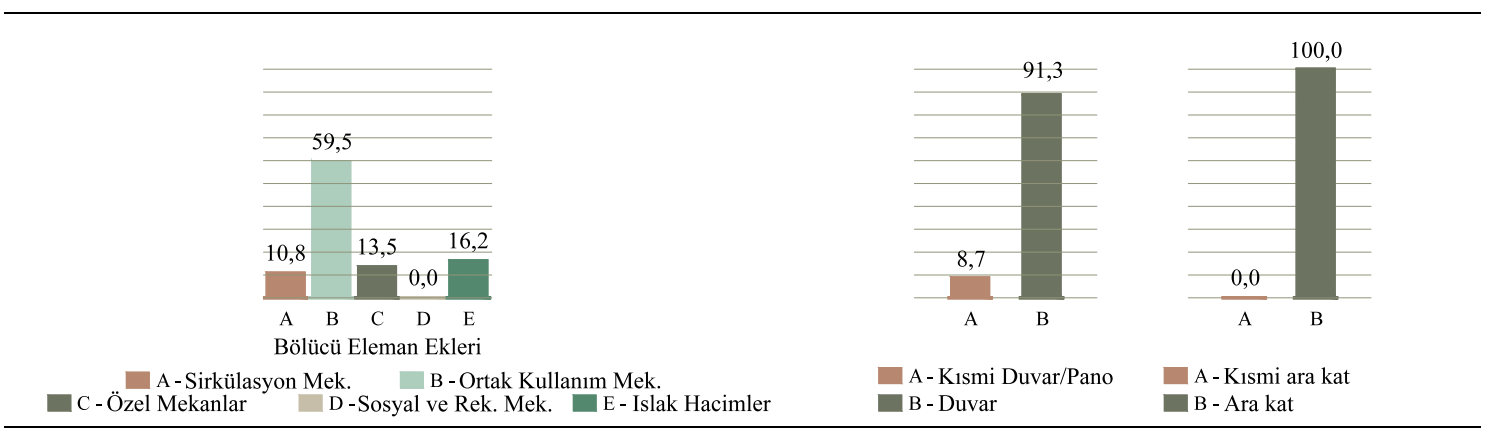

Şekil 10. Bölücü eleman eklerinin mekan gruplarına (sağda) ve türlerine (solda) göre dağılımı 
Bu elemanların türlerine göre dağılımına bakıldığında bölücü eleman eklerinin düşeyde neredeyse tamamının duvarlar olduğu, çok azının ise tavana kadar uzanmayan kısmi panolar şeklinde kullanıldığı, yatayda ise tamamının ara kat döşemesi olduğu (Şekil 10), kaldırılan bölücü elamanların ise bazı özgün duvarlar olduğu (Şekil 11) görülmektedir.

Ağırlıklı olarak ortak kullanım mekanlarında kullanılan bölücü eleman ekleri (Şekil 10) bodrum katta ve giriş katının güney kısmında, derslikleri, çalışma odalarını ve bu mekanlara bağlantıyı sağlayan koridorları oluşturabilmek için özgün mekanı düşeyde boylu boyuna bölen duvarlar şeklinde olmuş ve özgün plan şemasının algılanmasını engellemiş, yatayda ise giriş katının güney ve kuzey mekanlarını boydan boya bölen ara kat döşemesi olmuş ve özgün mekan hacminin algılanmasını etkilemiştir. Islak hacimlerde ise tavana kadar uzanmayan kısmi panolar bölücü elemanlar olarak tercih edilmiştir.

Ağırlıklı olarak ortak kullanım mekanlarında kullanılan bölücü eleman ekleri (Şekil 10) bodrum katta ve giriş katının güney kısmında, derslikleri, çalışma odalarını ve bu mekanlara bağlantıyı sağlayan koridorları oluşturabilmek için özgün mekanı düşeyde boylu boyuna bölen duvarlar şeklinde olmuş ve özgün plan şemasının algılanmasını engellemiş, yatayda ise giriş katının güney ve kuzey mekanlarını boydan boya bölen ara kat döşemesi olmuş ve özgün mekan hacminin algılanmasını etkilemiştir. Islak hacimlerde ise tavana kadar uzanmayan kısmi panolar bölücü elemanlar olarak tercih edilmiştir.

Bölücü eleman eklerinde olduğu gibi kaldırılan özgün elemanlarda da ağırlık ortak kullanım mekanlarında rastlanmaktadır (Şekil 11). Giriş katının güney ve kuzey kısmındaki mekanlarda yapının önceki restorasyonunda kaldırılan özgün bölücü duvarlar, yeniden kullanım projesinde çok amaçlı salon, derslikler ve çalışma odalarının bulunduğu mekanlara denk gelmesi nedeniyle tamamlanmamıştır.

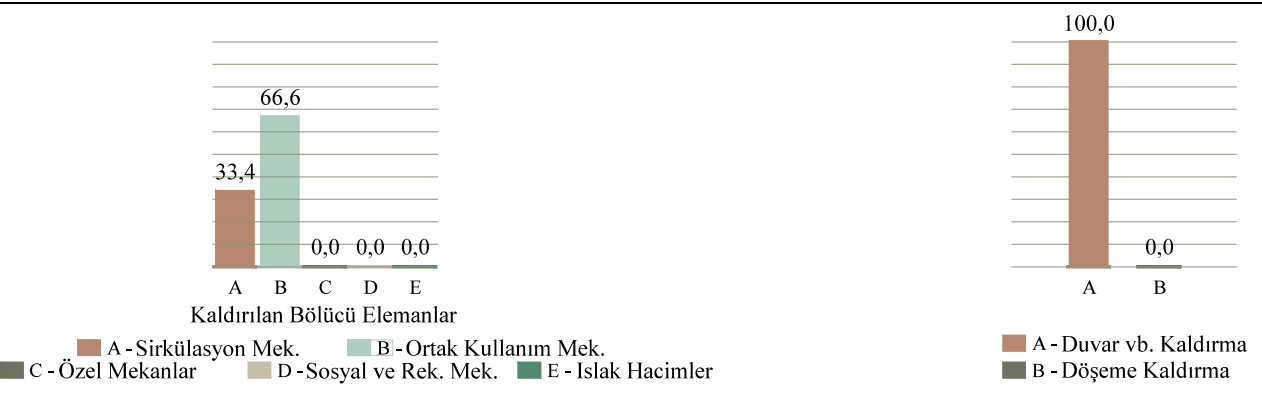

Şekil 11. Kaldırılan bölücü eleman eklerinin mekan gruplarına (sağda) ve türlerine (solda) göre dağılımı

- Sirkülasyon ekleri ve kaldırılan sirkülasyon elemanları:

Yapıya yeni merdiven ve basamaklar eklendiği gibi günümüze ulaşmadığı halde tamamlanmayan özgün merdivenlerinde olduğu görülmektedir.

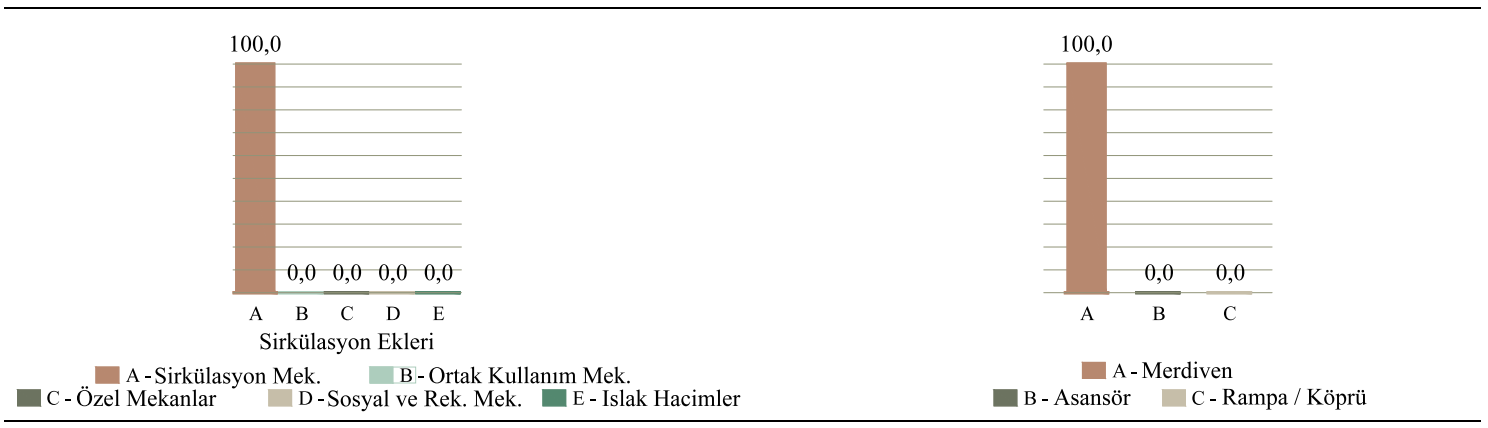

Şekil 12. Sirkülasyon eklerinin mekan gruplarına (sağda) ve türlerine (solda) göre dağılımı 
Sadece sirkülasyon mekanlarında rastlanan bu ekler (Şekil 12), ana girişin olduğu holden üst kata bağlantı sağlamak amacıyla önceki kullanımında eklenen ancak yeniden kullanımında da işlevsel olduğu için korunan merdiven ile bodrum katta alt kotta kalan çalışma odalarına ulaşmak için koridora eklenen basamaklardan oluşmaktadır. Yapının iki katlı olması nedeniyle asansör eklenmediği, engelli erişimi içinse merdivenlere katlanabilir özel bir düzenek yerleştirildiği görülmektedir.

Kaldırılan özgün sirkülasyon elemanlar ise ortak kullanım mekanları ve sslak hacimlere denk gelmektedir (Şekil 13). Ana girişin güney kısmındaki mekandan çatı katına bağlantı sağlayan ancak önceki restorasyonunda kaldırıldığı için günümüze ulaşmayan ve yeniden kullanımında da tamamlanmayan ana merdiven ile yeni kurgusunda iç mekanla ilişkilendirilen bodrum kattaki bağımsız mekanın özgün halinde bahçeden bağlantısını sağlayan merdivenin kaldırılması şeklinde olmuştur.

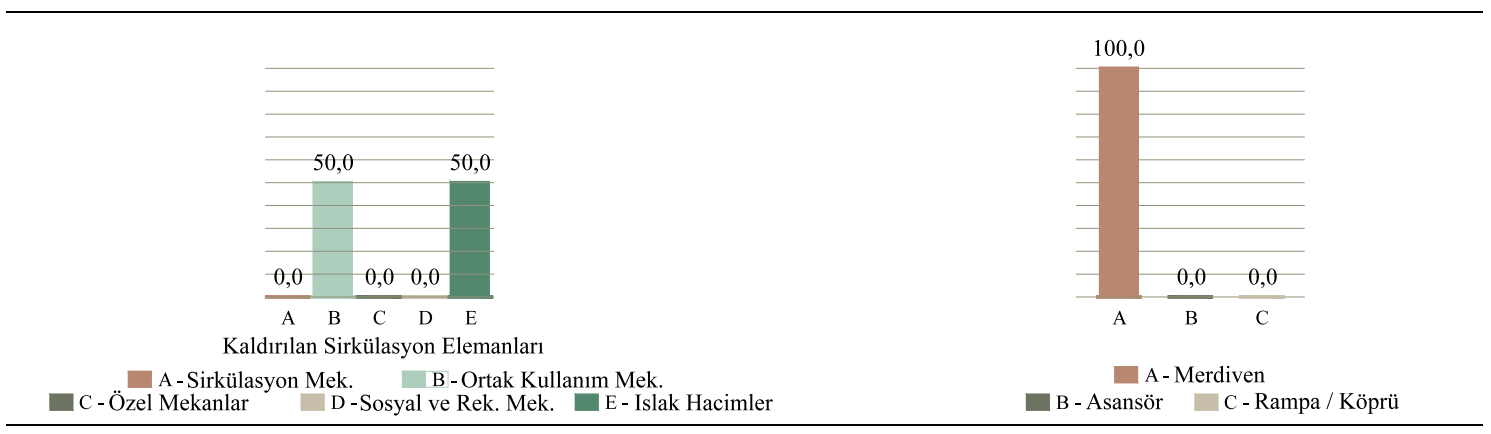

Şekil 13. Kaldırılan sirkülasyon elemanlarının mekan gruplarına (sağda) ve türlerine (solda) göre dağılımı.

\section{- Yüzey kapatan ekler:}

Yapının restorasyonu sonrasında bazı mekanlarda özgün tavanı bazı mekanlarda ise özgün döşemeyi kaplayan ekler yapılmıştır. Bunların türlerine bakıldığında ise tavan yüzeyinde asma tavan ile nadiren kısmi asma tavan, döşemede ise kotlamalar oluşturan platformlar kullanıldığı görülmektedir (Şekil $14)$.

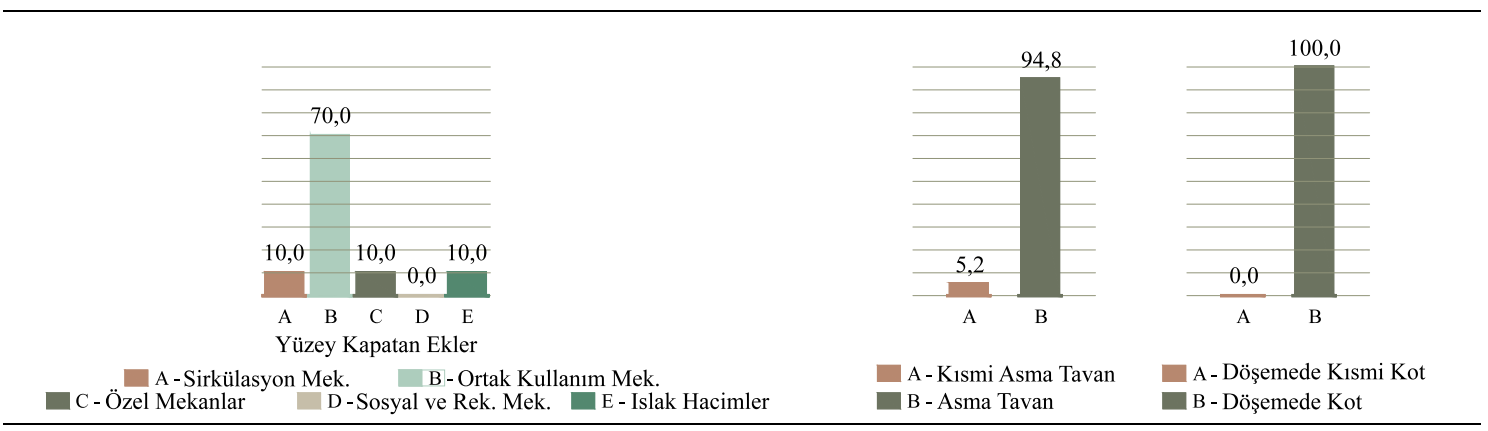

Şekil 14. Yüzey kapatan eklerin mekan gruplarına (sağda) ve türlerine (solda) göre dağılımı.

Ağırlıklı olarak ortak kullanım mekanlarında görülen bu ekler (Şekil 14) bodrum katta çalışma odaları ve toplantı salonunda, giriş katta güneyde derslikler ve koridorda, kuzeyde çok amaçlı salonda özgün volta döşeme dokusunu tümüyle kapatan asma tavanlardır. Bu asma tavan sadece bodrum kat koridorunun bir kısmında özgün volta döşemenin algılanacağı şekilde kısmen uygulanmıştır. Ayrıca çok amaçlı salonda farklı kotlar oluşturmak içinde platformlar kullanılarak özgün döşemenin üstü de örtülmüştür. 


\section{c. Strüktür ve Elemanlara Müdahaleler Açısından Değerlendirme}

Yapının yeniden kullanımına yönelik restorasyonunda özgün mimari strüktür ve elemanlara bakım çalışmalarının yanı sıra bütünleme ve yenileme gibi onarım çalışmalarının yapıldığı, yeni mimari strüktür ve elemanların da kullanıldığı görülmektedir.

Özgün mimari strüktür ve elemanlara müdahale biçimleri değerlendirildiğinde ağırlıklı olarak yenileme çalışmalarının yapıldığı, mekan gruplarına göre dağılımına bakıldığında ise ortak kullanım mekanları, özel mekanlar ve ıslak hacimlerde ağırlıklı olarak yenileme çalışmalarının yapıldığı, sirkülasyon mekanlarında ise bakım ve yenileme çalışmalarının eşdeğer olduğu görülmektedir. Sosyal ve rekreatif mekanlarında ise tamamen bütünleme çalışmaları yapılmıştır (Şekil 15).

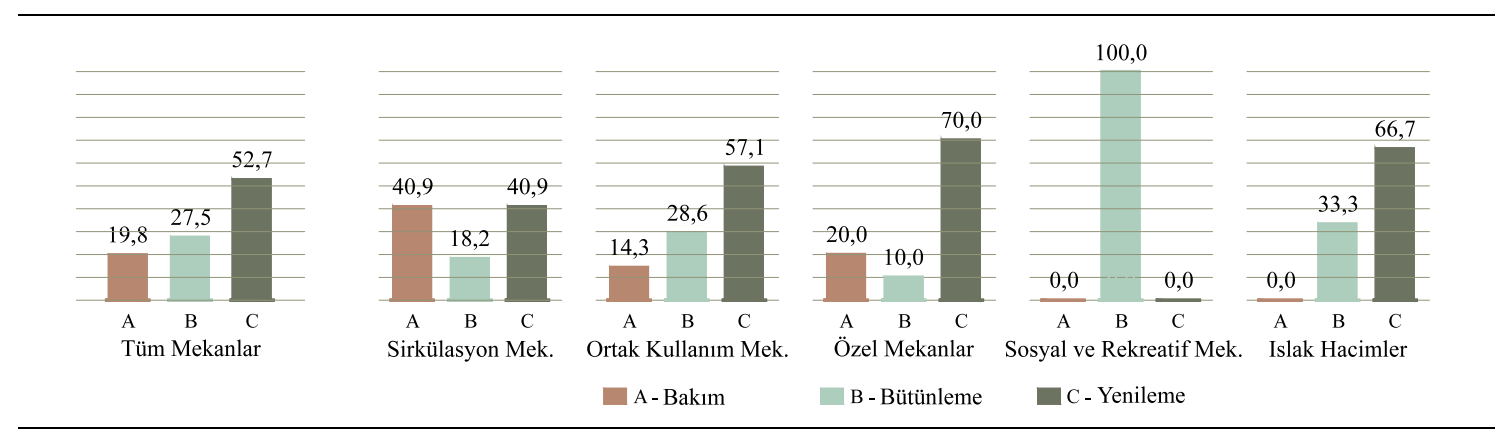

Şekil 15. Mimari strüktür ve elemanlara müdahale türlerinin yapı ve mekan gruplarına göre dağılımı.

Müdahale biçimlerinin mimari elemanlara göre dağılımına baktığımızda ise volta döşeme, çelik kolon, çelik kiriş ve ahşap çatı makası gibi yapının özgün kimliğini oluşturan özgün elemanlarda ağırlıklı olarak bakım çalışmaları yapıldığı, sıvalı duvarların aynı malzemeyle, dökme mozaik zeminin ise farklı malzemelerle yenilendiği, pencere doğramaları, kapı ve günümüze ulaşmayan doğu cephesindeki çıkmanın tüm mimari elemanlarının bütünleme çalışmalarında ise özgünden farklı zıt malzemeler kullanıldığı görülmektedir. Sonradan eklenen merdivenler ve kapılarda zıt malzemeler kullanılırken duvarlarda özgün duvarlarla benzer sıvalı duvarlar kullanılmıştır.

Özgün mimari strüktür ve elemanların yenileme çalışmalarında yapının tümü değerlendirildiğinde ağırlıklı olarak aynı malzemelerin tercih edildiği, mekan gruplara göre dağılımına bakıldığında ise ortak kullanım mekanlarında benzer malzemelerin, sirkülasyon mekanları ve özel mekanlarda ise zit malzemelerin ağırlıklı olarak kullanıldığı, ıslak hacimlerin ise tamamında özgün elemanlardan farklı zıt malzemeler kullanıldı̆̆ görülmektedir (Şekil 16).
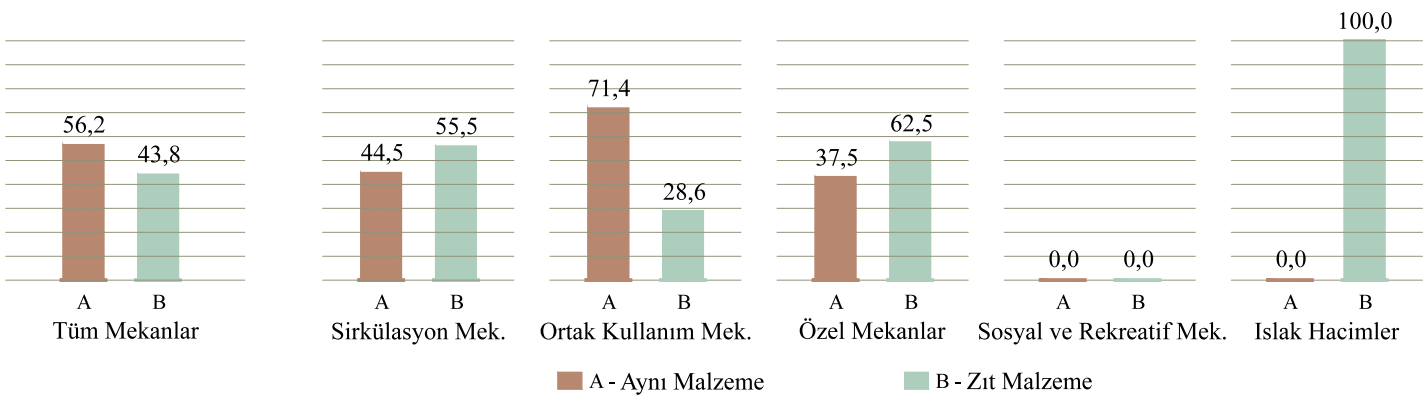

A - Aynı Malzeme

B - Zit Malzeme

Şekil 16. Mimari strüktür ve elemanların yenileme çalışmalarında malzeme seçim yaklaşımları ve mekan gruplarına göre dağılımı.

Özgün mimari strüktür ve elemanların bütünleme çalışmalarında ise hem yapının tümü değerlendirildiğinde hem de mekan gruplarına göre dağılımına bakıldığında günümüz teknolojisiyle uygulanmış özgün malzemeden farklı, zit malzemeler kullanıldığg görülmektedir (Şekil 17). 


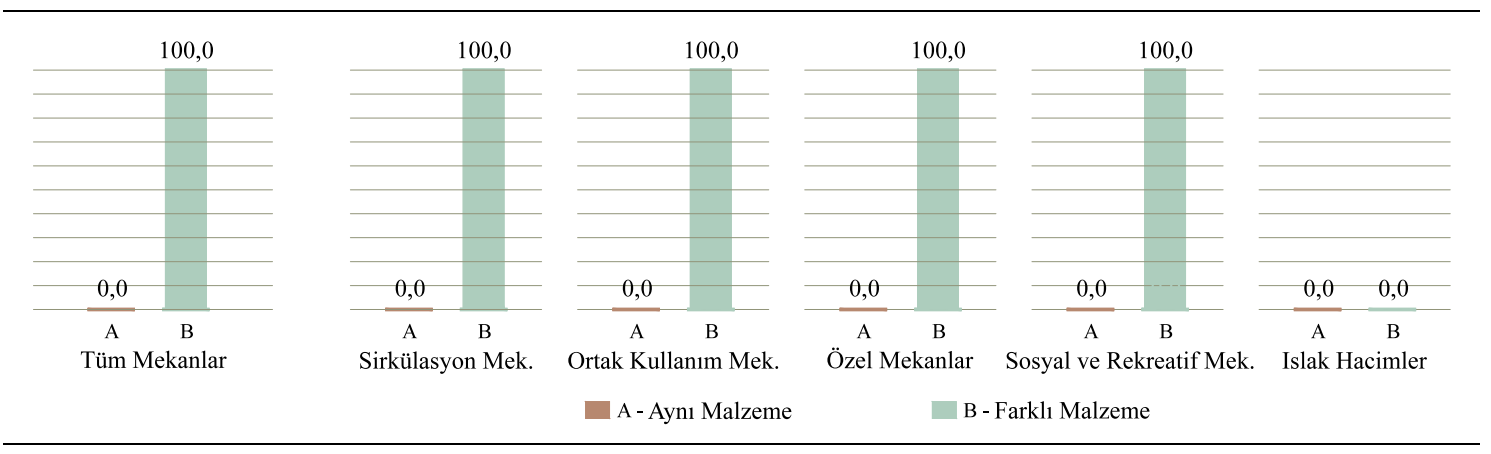

Şekil 17. Mimari strüktür ve elemanların bütünleme çalışmalarında malzeme seçim yaklaşımları ve mekan gruplarına göre dağılımı.

Yeni eklenen mimari elemanlara bakıldığında benzer ve zıt malzemelerin eşdeğer sıklıkla kullanıldığı, özgünü taklit eden malzemelerin ise hiç kullanılmadığı, mekan gruplarına göre dağılımına bakıldığında ise sirkülasyon mekanları, özel mekanlar ve islak hacimlerde ağırlıklı olarak zit malzemeler, ortak kullanım mekanlarında ise benzer malzemeler kullanıldığı görülmektedir (Şekil 18).
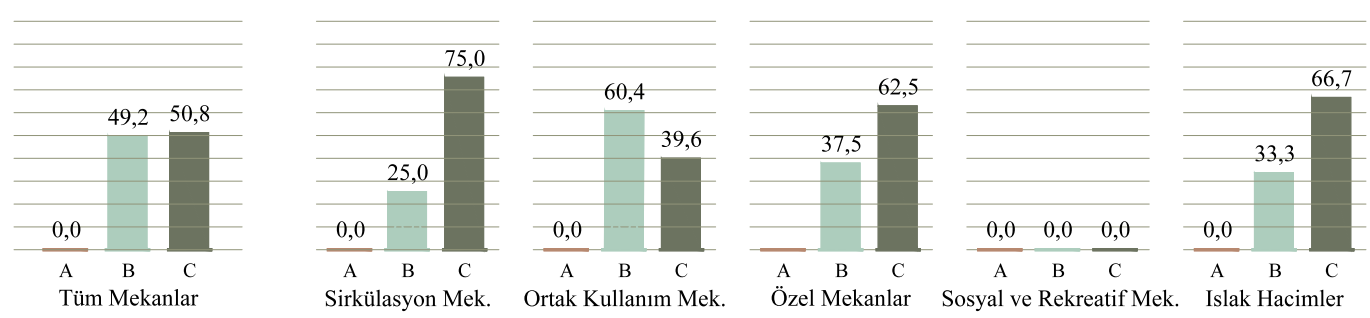

A - Taklit Malzeme Yaklaşımı B - Benzer Malzeme Yaklaşım ㄷ - Zit Malzeme Yaklaşımı

Şekil 18. Yeni eklenen mimari elemanların malzeme seçim yaklaşımları ve mekan gruplarına göre dağılımı.

\section{Sonuçlar ve Öneriler}

Elde edilen bugular değerlendirildiğinde İspirtohane Binasının yeniden kullanım çalışmaları nedeniyle iç mekanda maruz kaldığı etkileri şu şekilde sıralayabiliriz;

\section{a. Uygulanan müdahale yöntemleri açısından;}

Yapının önceki kullanımından kaynaklı niteliksiz dönem eklerinin temizlendiği, yapısal bozulmaların engellendiği, sağlamlaştırma ve bütünleme işlemlerinin yapıldığı, yeni işlev programlarına bağlı olarak yeni mimari elemanların eklendiği, yapının önceki kullanımlarında eklenmesine rağmen yeni kullanımı için işlevsel bulunan yeni merdiven ve ara kat döşemesinin ise kaldırılmadığı görülmektedir.

\section{b. Mekânsal kurguya müdahaleler açısından;}

Mekansal kurguya müdahale açısından değerlendirildiğinde, doğu cephesinde var olduğu restitüsyon çalı̧̧malarında belgelenen ve bu nedenle bütünleme tekniğiyle tamamlanan çıkmanın günümüz malzeme ve tekniği ile uygulanması nedeniyle eski-yeni ilişsisini net şekilde algılatması ve yapı bütünlüğü koruması açısından önemli olduğu, fakat ağırlıklı olarak ortak kullanım mekanlarının kısmen ise özel mekanlar ve sslak hacimlerin yapı özgün kurgusuyla uyuşmaması nedeniyle bir takım müdahaleler gerektirdiği ve bu müdahaleler sonucunda,

- Özellikle ortak kullanım mekanları ve özel mekanlarda ihtiyaç duyulan mekanları oluşturabilmek için düşeyde ve yatayda kullanılan bölücü elemanlar nedeniyle özgün mekan boyutları algısının kaybedildiği,

- Bu bölücü elemanların özgün mimari elemanlara teması nedeniyle zarar verdiği,

$\mathbf{2 6 4 | P}$ a g e

WWW.iiste.org 
- Yine ağırlıklı olarak ortak kullanım mekanları ve özel mekanlarda kullanılan asma tavanların yatayda özgün mekan hacminin algısını etkilediği ve özgün tavan dokusunu gizlediği,

- Bodrum kata ulaşılan özgün kapının iptal edilerek merdivenin kaldırılması, bazı özgün duvar yüzeylerindeki açıklıkların kapatılması, bazı özgün duvarlarda ise yeni açıklıklar oluşturulması gibi kısmi eklerin yanı sıra sirkülasyon mekanlarına eklenen yeni merdiven için özgün döşemede boşaltmanın yapıldı $\breve{g} 1$

için özgün yapıyı olumsuz etkilediği görülmektedir.

\section{c. Mimari strüktür ve elemanlara müdahaleler açısından:}

- Yapıların tamamında, işlevleri gereği tüm kullanıcılar tarafindan yoğun şekilde kullanılan sirkülasyon mekanları ile sosyal ve rekreatif mekanlarında, duvar, kolon, kiriş, çatı makası vb. gibi tarihi endüstri yapılarının kimliğini oluşturan özgün elemanların ağırlıklı olarak bakım yapılarak korunduğu,

- Tüm mekan guruplarında ki bütünleme çalışmalarının yanı sıra sirkülasyon mekanları ve özel mekanları yenileme çalışmalarında da ağırlıklı olarak günümüz malzemeleri tercih edilerek zıtlık oluşturulduğu için eski-yeni ilişkisinin kurularak özgün malzemelerden kolaylıkla ayrılabildiği

gibi olumlu etkilerin yanı sıra,

- Ortak kullanım mekanlarına yeni eklenen mimari elemanların özgün ile benzer olmaları nedeniyle özgün elemanlardan ayırt edilemediği ve eski-yeni ilişkisinin kurulamadığı,

- Ortak kullanım mekanları ve özel mekanlarda mimari strüktür ve elamanların ağırlıklı olarak yenilenmeleri nedeniyle özgün mekân algısının zayıfladığı,

- Islak hacimlerde özgün mimari strüktür ve elamanların yenilenmesi ve yeni mimari eleman kullanımının ağırlıkta olması nedeniyle özgün mekan algısının tamamen kaybolduğu

gibi özgün yapıya olumsuz etkilerin olduğu görülmektedir.

Sonuç olarak gelişen ve değişen teknolojiye bağlı olarak, üretim tekniklerinin de değişmesiyle işlevini kaybederek kullanım dışı kalan ve bu nedenle zamanla tahrip olarak yok olma tehlikesiyle yüz yüze olan İstanbul Endüstri Yapılarının önemli örneklerinden biri olan İspirtohane Binasının, yeni bir işlevle değerlendirilerek toplum hayatına kazandııılması yeniden kullanımın yararlı bir boyutu olarak karşımıza çıkmaktadır. Bu yararın yanı sıra, çalışmamızın başında da belirttiğimiz gibi işlev seçimi ve uygulanan müdahale yöntem ve tekniklerden kaynaklanan bir takım olumsuz etkilere maruz kaldığı da görülmektedir.

$\mathrm{Bu}$ anlamda benzer uygulamalarda, yeni işlevin yapı iç mekânına olumsuz etkilerinin en aza indirilebilmesi için öneriler şöyle sıralanabilir:

\section{a. Mekânsal kurgu açısından öneriler;}

Özgün yapının mekansal kurgusunun korunabilmesi açısından yeni işlev kurgusunun özgün işlev kurgusuyla uyum göstermesi önemlidir. Bu nedenle yeni işlev seçiminde yapıya etkilerin çok iyi irdelenerek restorasyon projelerinin geliştirilmesi gerekmektedir. Restorasyon çalışmaları esnasında işlev nedeniyle kurguya müdahale edilmesi gerekiyorsa da,

- Düşeyde kullanılacak bölücü elemanların sadece ihtiyaç duyulan mekân sınırlarını belirleyen, özgün mekânı tümden bölerek algısını zedelemeyen, panel, alçak duvar, donatı vb. gibi elemanlar kullanılmalı,

- Yatayda kullanılacak bölücü elemanlarla oluşturulacak ara katlarda, mekân algısını zayıflatmayacak yoğunlukta, galeri boşluğu bırakan ve özgün duvardan kopararak duvar yüzeyinde yer alan kapı, pencere, niş vb gibi elemanların bütünle ilişkilinin algısını engellemeyen çözümler üretilmeli,

- Teknik sistem vb gibi konfor gereksinimleri için özgün malzeme ve hacim etkisini engelleyen asma tavanlar yerine tavanda yüzer elemanlarla çözümler üretilmeli,

- Ayrıca yeni işlev programının gereksinim duyduğu mekânları oluşturabilmek için düşeyde ve yatayda çok sayıda bölücü elemanlar kullanarak özgün mekân algısını etkileyen uygulamalar yerine, özgün yapıyla uyumlu ek binalar içerisinde çözümlenerek ağır yükler getirecek birimlerin iç mekâna etkileri azaltılabilmelidir. 


\section{b. Özgün Mimari Strüktür ve elemanlara müdahaleler açısından öneriler;}

Yapıların mimari özelliklerini yansıtan mevcut mimari strüktür ve elemanları mümkün oldukça bakım yapılarak korunmalı, dönem özelliklerini yansıtan çözümlemeler getirilmelidir. Eğer mimari strüktür ve elemanlara müdahale edilmesi gerekiyor ise,

- Eksik mimari elemanların bütünleme çalışmalarıyla tamamlanması söz konusu olduğunda özgünle aynı malzemeler yerine günün teknoloji ve malzemeleri kullanılarak özgün olanından ayırt edilebilerek yapının mimari özelliklerine zarar vermeyen uygulamalar yapılmalı,

- Yeni eklenen mimari elemanların yapıların mimari özelliklerini yansıtan özgün elemanlarla aynı teknik ve malzeme kullanılarak taklit yaklaşımlarından kaçınılmalı,

- Yeni eklenen mimari elemanların yapıların mimari özelliklerini yansıtan özgün mimari elemanlarla temasından kaçınılarak, hem geçmiş ve günümüz arasında bir ara kesit oluşturarak uyum sağlanmalı, hem de ileride ki restorasyon çalışmalarında kolayca temizlenerek özgün elemanlara zarar vermemesi sağlanmalıdır.

\section{Kaynaklar}

Akın, N., Kahya, Y. ve Salman, Y. (2002) "20. Yüzyıl Endüstri Mirasının Korunmasına Bir Örnek: Bakırköy İspirtohane Binası", Arrademento Mimarlık, 5, 110-116.

Altınok, Ü. (1998). Binaların Yeniden Kullanımı, YEM yayınları, İstanbul.

Alsaç, Ü. (1995). Türkiye'de Restorasyon, İletişim Yayınları, İstanbul.

Ahunbay, Z. (1996). Tarihi Çevre Koruma ve Restorasyon, YEM yayınları, İstanbul.

Ahunbay, Z. (1997). Anıt maddesi, Eczacıbaşı Sanat Ansiklopedisi, I.Cilt, YEM Yayınları, İstanbul.

Bakırköy Musuki Vakfı (2009, 15 Mayıs) Erişim Adresi

https://www.google.com/maps/place/Bakırköy+Musiki+Vakfi/@40.9849235,28.8439928,336m/dat $\mathrm{a}=! 3 \mathrm{~m} 1$ ! $1 \mathrm{e} 3$ ! $4 \mathrm{~m} 12$ ! $1 \mathrm{~m} 6$ !3m5!1 s0x14caa35b2950368b:0xe2a9cb659154360f!2sCafe+İspirtohan $\mathrm{e} ! 8 \mathrm{~m} 2 ! 3 \mathrm{~d} 40.9849201 ! 4 \mathrm{~d} 28.8446252 ! 3 \mathrm{~m} 4$ ! $1 \mathrm{~s} 0 \mathrm{x} 0: 0 \mathrm{xf} 2 \mathrm{~d} 0689 \mathrm{bb} 8455 \mathrm{cc} 5$ !8m2!3d40.9847992!4d2 8.8448325

Başa, B.A. (2002). Hızlı Gelişme Sürecinde İşlev Değiştirmeye Zorlanan yapıların Büyük kent Modeli İçinde İrdelenmesi, Yüksek Lisans Tezi, Marmara Üniversitesi, Güzel Sanatlar Enstitüsü, İstanbul.

Dayev, P., Cruickshank, D. (1988). Working With Old Buildings, The Architectural Review, 1094, (4), 23-28.

Ersen, A. (1992). Yeniden İşlevlendirilen Tarihi Yapılar, Modern Ekler ve Çağdaş Tasarım, Arredamento Dekorasyon, 37, (5), 102-105.

Engin, E. (2009). Tarihi Yapıların Yeniden Kullanımında İç Mekana Etkilerin İncelenmesi için Bir Yöntem Önerisi; İstanbul Endüstri Yapıları Örneği, Doktora Tezi, Karadeniz Teknik Üniversitesi, Fen Bilimleri Enstitüsü, Trabzon.

Feilden, M.B. (2003). Conservation of Historic Buildings, Third Edition, Elsevier ; Architectural Press.

İTÜ Geliştirme Vakfı Ar-Ge İşletmesi (1998). Bakırköy İspirtohane Binası "Konservatuar-Kültür Merkezi” Restorasyon ve Yeniden Kullanım Proje Raporu, İstanbul 1 Numaralı Kültür ve Tabiat Varlıklarını Koruma Kurulu Arşivi, İstanbul. 
Kıran, S. (1993). Anıtsal yapılara Ek Yapı Tasarımı ve Ek Yapı Tasarımına Etki Eden Etkenler, Yüksek Lisans Tezi, Yıldız Teknik Üniversitesi, Fen Bilimleri Enstitüsü, İstanbul.

Kuban, D. (2000). Tarihi Çevre Korumanın Mimarlık Boyutu, Kuram ve Uygulama, Yapı Endüstri Merkezi Yayınları, İstanbul.

Kuleli, E. (1998). Özgün İşlevini Sürdüremeyen Anıtların Yeniden Kullanım Sorunları, Yüksek Lisans Tezi, Dokuz Eylül Üniversitesi Fen Bilimleri Enstitüsü, İzmir.

Madran, E. ve Özgönül, N. (2005). Kültürel ve Doğal Değerlerin Korunması, TMMOB Mimarlar Odası yayınları, Ankara.

Omay Polat, E. E., Can, C. (2008). Modern Mimarlık Mirası Kavramı: Tanım ve Kapsam. Megaron YTÜ Mimarlık Fakültesi Elektronik Dergisi,(2), 177-186. Erişim: http://www.journalagent.com/megaron/pdfs/MEGARON-07078-ARTICLE-POLAT.pdf (Ocak 21, 2009)

İstanbul 2 Numaralı Kültür ve Tabiat Varlıklarını Koruma Kurulu Arşivi (1998), 5178 Pafta, 1185 Ada, 1 Parsel Nolu Dosya

İTÜ Mimarlık Fakültesi İspirtohane Ekibi (2000), Mimarlık, 294, 30-31. 